\title{
Lake level controls the recurrence of giant stromatolite facies
}

MIQUELA INGALLS ${ }^{1,2^{*}}$, ANNE C. FETROW ${ }^{1}$, KATHRYN E. SNELL $^{1}$, CARIE M. FRANTZ $^{3}$ and ELIZABETH J. TROWER ${ }^{1}$

1 Department of Geological Sciences, University of Colorado, Boulder, CO, USA (E-mail: ingalls@psu.edu)

2 Division of Geological and Planetary Sciences, California Institute of Technology, Pasadena, CA, USA

3 Department of Earth and Environmental Sciences, Weber State University, Ogden, UT, USA

*Current address: Department of Geosciences, Pennsylvania State University, University Park, PA, USA

\section{Associate Editor - Mike Rogerson}

Short Title - Controls on stromatolite facies

\section{ABSTRACT}

Stromatolites have often served as a diagnostic carbonate facies for deep-time palaeoclimatic and geobiological studies because they may form under favourable environmental conditions for microbially mediated carbonate production. 'Giant' $(<5 \mathrm{~m})$ stromatolites occur in the Laney Member of the Eocene Green River Formation in the Vermillion Creek section of the Sand Wash Basin (northwest Colorado, USA). Giant stromatolite growth was hypothesized to have been promoted by both availability of large substrates as nucleation sites and physicochemical factors, including increased calcium carbonate mineral saturation states due to the generally warmer Eocene climate and a dynamic period in Lake Gosiute's hydrological balance. Depositional horizons of giant stromatolites were observed at two distinct stratigraphic levels, which demonstrated that the formation of the giant morphotype was not a unique occurrence, and provided an opportunity to examine both onset and cessation of stromatolite development. Coincident increases in carbonate clumped isotope-derived

This article has been accepted for publication and undergone full peer review but has not been through the copyediting, typesetting, pagination and proofreading process, which may lead to differences between this version and the Version of Record. Please cite this article as doi: 10.1111/SED.12967

This article is protected by copyright. All rights reserved 
temperatures, the carbon and oxygen isotopic compositions of lake water $\left(\delta^{18} \mathrm{O}_{\mathrm{w}}\right)$, carbonate mineral saturation states $(\Omega)$ estimated by ooid size, and salinity estimated by ostracod assemblages demonstrated that formation of giant stromatolites was facilitated by lake level drawdown. Decreased lake levels: (i) promoted carbonate precipitation; and (ii) positioned benthic microbial communities within the photic zone. Field and petrographic analyses revealed that the giants preserved micritic laminations, 'trapped and bound' grains, and aragonite fans, interpreted as reflecting contributions from both microbially mediated and abiotic carbonate mineral precipitation. Field and microscopic sedimentological and stable isotope data indicated that giant stromatolite growth ceased as a result of subaerial exposure of mounds during lake level lows. Although microbial mediation of carbonate chemistry was seemingly important for initiation of stromatolite growth, this work demonstrated that stromatolite macromorphology was dominantly controlled by availability of large substrates, lake level and resultant solute chemistry, i.e. increased $\Omega$.

Keywords Carbonate, clumped isotopes, Green River Formation, stromatolite. 


\section{INTRODUCTION}

Stromatolites - laminated, typically carbonate structures that accrete away from a point or surface and commonly, but not necessarily, of microbial origin (Semikhatov et al., 1979) - exhibit diverse morphologies such as digitate shrubs, flat mats, columns and domes or heads. Importantly, some stromatolite morphologies (for example, shrubs, clotted, crinkly laminites and multi-metre domes/cones) have characteristically high initial porosities critical to oil retention and recovery. In part, due to the discovery of microbial shrubs in the Lower Cretaceous Pre-Salt oil play in the Santos and Campos basins offshore of Brazil (Carminatti et al., 2008) and the Kwanza Basin offshore of Angola (Greenhalgh et al., 2012), there is a growing desire to understand the chemical and environmental conditions under which stromatolite morphotypes form. For example, modern stromatolites are mostly limited to shorelines of hydrologically restricted marine and lacustrine basins. Knowledge of the allocyclic (i.e. climate and tectonics) and autocyclic (i.e. microbes and lake chemistry) controls on the development of stromatolite morphologies that are found in geophysical surveys of subsurface systems should enable better predictions of chemical and physical attributes important to reservoir quality (for example, primary and secondary porosity, lateral continuity and organic preservation potential). Although stromatolite macromorphologies and micromorphologies (observable at the field-scale and microscope-scale, respectively) are likely influenced by both microbial community composition and local aqueous chemistry, the mechanics of how these factors control morphology are debated (Grotzinger \& Knoll, 1999; Arenas \& Pomar, 2010; Bosak et al., 2013; Arenas \& Jones, 2017; Martin-Bello et al., 2019). On modern Earth, stromatolite formation is primarily limited to chemical precipitation by in situ microbial mediation of water chemistry or trapping and binding by cyanobacterial filaments in shoreline environments. Grotzinger \& Knoll (1999) posited that the history of modern marine stromatolite discovery and the uncertain applicability of these modern analogues to Precambrian environments has divided interpretations of ancient stromatolite morphology. Fabrics indicative of both biological and abiotic processes have been identified within individual settings in the ancient stromatolite record, discernable primarily by carbonate textures and proxies for aqueous chemistry, hydrology and temperature (e.g. Grotzinger and Knoll, 1999; Bartley et al., 2000; Sumner \& Grotzinger, 2000, Frantz et al., 2014). Lacustrine 
microbial carbonates of the Eocene Green River Formation (Colorado, Utah and Wyoming, USA) have been described for a century (Bradley, 1929; Surdam \& Stanley, 1979; Roehler, 1993). However, studies of the autocyclic and allocyclic controls on lacustrine stromatolite formation have been limited (Arp et al., 2005; Frantz et al., 2014; Awramik \& Buchheim, 2015a; Roche et al., 2018; Martin-Bello et al., 2019) despite the use of other Green River Formation outcrops for palaeoclimate and tectonic reconstruction (Carroll et al., 2008; Doebbert et al., 2010; Smith et al., 2014, 2015; Graf et al., 2015).

Stromatolites with up to $5.5 \mathrm{~m}$ of vertical relief and characteristic tube structures at their cores have been described in the Laney Member of the Green River Formation in the upper Early Eocene Sand Wash Basin of western Colorado (Roehler, 1993; Awramik \& Buchheim, 2015b). The environmental (for example, lake level and climate), physicochemical (for example, water temperature and mineral saturation state) and/or biological factors that resulted in multi-metre tall stromatolite formation remain enigmatic. The goal of this study was to identify the roles of allocyclic (i.e. hydroclimate) and autocyclic (i.e. microbiology and lake chemistry) factors on the growth and distribution of a specific stromatolite growth habit - multi-metre stromatolite heads, herein referred to simply as 'giants'.

Large, lacustrine shoreline stromatolite mounds and microbialite-oolite facies assemblages, such as those found in the Laney Member, are productive reservoir and baffle facies in the Green River Formation (for example, West Willow Creek oil field; Chidsey et al., 2015) and elsewhere in the lacustrine record [for example, Upper Jurassic Smackover Formation of north-east Gulf of Mexico (Mancini et al., 2004, 2008); Miocene terminal carbonate complex, Spain (Lipinski et al., 2013)]. A systematic understanding of initiation, accretion and cessation of the multi-metre mound morphotype is key to creating better predictive reservoir facies models for exploration.

Here, a sedimentological and geochemical framework was developed for understanding the roles of aqueous chemistry and lake level in facilitating giant stromatolite accretion and cessation in hydrologically restricted basins. Field and petrographic sedimentological and micropaleontological

This article is protected by copyright. All rights reserved 
observations, an ooid size-based proxy for carbonate mineral saturation state $\left(\Omega=[\mathrm{Ca}]\left[\mathrm{CO}_{3}\right] / \mathrm{K}_{\mathrm{sp}}\right.$, where $\mathrm{K}_{\mathrm{sp}}$ is the solubility product constant), and carbon, oxygen and clumped isotope compositions of lacustrine carbonate were used to relate changing environmental conditions to the presence-absence of giants. New data indicated that large substrates deposited in the photic zone of a long-lived lake were key to seeding the growth of giants, while lake level fall and subaerial exposure ceased the growth of giants.

\section{GEOLOGICAL SETTING}

\section{Tectonics and geochronology}

The Eocene Green River Formation strata were deposited from $c a 53.5$ to $48.5 \mathrm{Ma}$ in a climatically and tectonically dynamic environment within three intermittently connected lakes (Fossil Lake and lakes Gosiute and Uinta; Fig. 1A; Smith et al., 2003). The Sand Wash Basin was the southernmost sub-basin of Lake Gosiute with a depositional axis abutting the north-eastern curvature of the Uinta Mountains. The anticlinal Uinta Mountains experienced continuous uplift and deformation from the activation of the Late Cretaceous to Palaeocene regional-scale thrust faults along the north flank of the Laramide orogeny (e.g. Crews \& Ethridge, 1993) to the early Eocene activation of the Sparks Ranch (SRT) and Henry's Fork north-bounding thrust faults (Fig. 1A; Bradley, 1995; Johnston \& Yin, 2001). Flexural subsidence of the Green River basins led to the development of freshwater lakes (St. John et al., 1984). The study section of the Laney Member of the Green River Formation at Vermillion Creek was on the hanging wall of the SRT (Fig. 1A).

A tuff from the transition from the underlying Wilkins Peak Member to the Laney Member yielded a weighted-mean biotite ${ }^{40} \mathrm{Ar} /{ }^{39} \mathrm{Ar}$ age of $49.92 \pm 0.10 \mathrm{Ma}$ (Smith et al., 2010). A tuff from the Upper LaClede Bed (ULB) of the Laney Member yielded a sanidine weighted-mean ${ }^{40} \mathrm{Ar} /{ }^{39} \mathrm{Ar}$ age (31 multigrain analyses) of $49.24 \pm 0.18 \mathrm{Ma}$, approximating the end of Laney deposition.

\section{Early Eocene climate}

The apex of global warmth for the Cenozoic, the Early Eocene Climatic Optimum (EECO, ca 53-49 Ma; Westerhold et al., 2020), was essentially coeval with almost all of Green River Formation 
deposition (Smith et al., 2008, 2010; Machlus et al., 2015). The Laney Member was deposited immediately following the EECO (Smith et al., 2014). In addition to generally warm conditions, numerous rapid ( $<\mathrm{ca} 200 \mathrm{kyr}$ ) global warming events occurred throughout the Early Eocene until $c a$ 47 Ma (Lourens et al., 2005; Kirtland-Turner et al., 2014; Lauretano et al., 2015; Westerhold et al., 2020). These hyperthermal events were characterized by coincident negative carbon and oxygen isotope excursions in marine benthic foraminifera that reflected rapid global warming driven by injections of isotopically light carbon into the ocean-atmosphere system (Lourens et al., 2005; Kirtland-Turner et al., 2014).

In the western US, the regional temperature response to global warmth during this time has been reconstructed predominantly by leaf margin analysis of fossil floras, and oxygen and clumped isotope thermometry of terrestrial carbonates. Mean annual temperature (MAT) estimated by leaf margin analysis from the Early Eocene Green River Basin was $15.2^{\circ} \mathrm{C}$ (Greenwood \& Wing, 1995). Clumped isotope estimates of stromatolite formation temperatures from the Rife Bed of the Green River Formation suggested warm season water temperatures of $c a 35^{\circ} \mathrm{C}$ and $28^{\circ} \mathrm{C}$ within and below the photic zone, respectively (Frantz et al., 2014).

Warm climates are also thought to lead to an enhanced hydrological cycle (e.g. Held \& Soden, 2006). Increased mean annual precipitation (MAP) during the early Eocene and rapid warming superimposed on top of already warm conditions likely led to an even more intense hydrological cycle. In addition, episodes of more extreme precipitation events may have complicated the expression of increased MAP overall (Carmichael et al., 2016, 2017, 2018). For example, the neighbouring Bighorn Basin (Wyoming) appeared to have gotten drier during the Palaeocene-Eocene Thermal Maximum - the largest of Palaeogene hyperthermals - but experienced unchanged or slightly wetter than background conditions during four subsequent Eocene hyperthermals (e.g. Abels et al., 2013, 2016).

The hydroclimate response of the lakes of the Green River basins to these hyperthermals is unknown. Leopold \& MacGinitie (1972) suggested that the Green River basin experienced regional 
cooling and an increase in precipitation amount in the Early Eocene. The presence of large, long-lived lakes in western North America's continental interior may have led to a warmer, more humid regional climate while additional forcings contributed to higher MAP in the early Eocene. For example, climate simulations conducted by Thrasher \& Sloan (2010) predicted that land surface areas adjacent to large lakes experienced an increase in MAP up to 30\% during the early Eocene. In the Green River and Uinta basins, in particular, the Thrasher \& Sloan (2010) LAKE model better matched proxy estimates for MAT and mean annual temperature range (MATR) than their model with no lake or marsh land cover but underpredicted MAP relative to proxy estimates from leaf physiognomy and oxygen isotopes (Wing \& Greenwood, 1993; Greenwood \& Wing, 1995; Wilf et al., 1998; Fricke \& Wing, 2004).

\section{Depositional setting}

The regional transition from a hot and arid climate to warm and humid one may have led to a freshening of lake water chemistry. The Laney Member deposited during the transition from a period of deep, long-lived saltwater to brackish-water in Lake Gosiute (Roehler, 1993), with an average sediment accumulation rate of $104 \pm 18 \mu \mathrm{m} / \mathrm{yr}$ (Smith et al., 2003). Bedded evaporites were absent from the lower Laney Member due to interconnection of lakes Gosiute and Uinta at the eastern end of the Uinta Mountains, which resulted in freshening and lack of salt deposition during lake contraction. The Lower LaClede Bed (LLB), the focus of this study, recorded ca $100 \mathrm{~m}$ of deposition under salt to brackish water conditions and was overlain by $c a 135 \mathrm{~m}$ of deposition under freshwater conditions in the Upper LaClede Bed (ULB) (Roehler, 1991). The LLB and ULB are separated by the volcaniclastic Buff Marker Bed (BMB) and a conformable 'fill to spill' surface that marks an increase in net water supply to Lake Gosiute (Carroll et al., 2008). The LLB was deposited when Lake Gosiute was underfilled. The ULB was deposited during the initial return to balance-filled conditions after a potentially large volcanic event and/or drainage capture of a higher altitude foreland river (Carroll et al., 2008). Partially silicified stromatolites from $<1$ to $3 \mathrm{~m}$ in diameter and $c a 5.5 \mathrm{~m}$ in height were common in nearshore and shoreline environments of the LLB (Surdam \& Stanley, 1979; Roehler, 1993). Oolitic and pisolitic limestone beds were deposited between and on top of stromatolite reefs and formed beaches (Roehler, 1993).

This article is protected by copyright. All rights reserved 


\section{METHODS}

\section{Field geology, sedimentology and petrography}

Forty-two metres of stratigraphic section were measured across two giant stromatolite horizons in the Vermillion Creek section of the Green River Formation, originally described by Awramik \& Buchheim (2015). Polished petrographic thin sections were prepared from representative samples of each facies (Fig. 2) by Spectrum Petrographics (Vancouver, WA, USA). Thin sections were examined and imaged in transmitted and reflected light using a Zeiss AxioImager M2 petrographic microscope (Zeiss, Jena, Germany). Grain composition was determined via point counting mosaics of each thin section using JMicrovision (Roduit, 2020) with 300 points counted per sample (Table 1). Cathodoluminescence (CL) characteristics of a subset of thin sections were analyzed using a Technosyn (CITL, Cambridge, UK) cold cathodoluminescence unit with beam settings of ca $14 \mathrm{KV}$ and a gun current of $c a 400 \mathrm{~mA}$. Exposure times for CL images varied with most exposures lasting 1 to 5 seconds.

\section{Saturation state calculations}

Trower et al. $(2017,2018,2020)$ demonstrated that ooid size reflects an equilibrium between precipitation and abrasion rates, which supports the application of ooid size measurements in the rock record to reconstruct $\Omega$ of ancient seawater or lake water (e.g. Li et al., 2020; Trower, 2020). Ooid diameters were measured from thin sections using JMicrovision (Roduit, 2020); when possible, 400 grains were measured per sample, but some samples contained $<400$ usable grains. Ooid diameters

were only measured from grains with clearly distinguishable nuclei, minimizing the effects of random cuts through grains, although measured diameters are still likely to slightly underestimate true grain diameters (Johnson, 1994). Measured ooid diameters were used to reconstruct variations in depositional $\Omega$ values (Table 2), assuming transport intermittency where grains are actively transported $5 \%$ of the time $(f=0.05)$ and at the threshold of suspension (Rouse number $\mathrm{P}=2.5)$. Both of these assumptions are based on constraints determined from modern ooids in Great Salt Lake, Utah, USA (Trower et al., 2020). Kinetic parameters for precipitation rates of calcite and aragonite at 
$25^{\circ} \mathrm{C}$ (consistent with clumped isotope temperature estimate) were selected from Zhong \& Mucci (1989). Uncertainty on transport intermittency contributes the most uncertainty to these calculations (Li et al., 2020; Trower et al., 2020); minimum and maximum $\Omega$ estimates were calculated by assuming $f=0.1$ and $f=0.01$, respectively.

\section{Stable carbon and oxygen isotope analyses}

Carbonates were powdered using a Dremel tool with a fine, diamond-coated bit. Within individual hand samples, $<1$ to $2 \mathrm{~mm}$ thick laminae or other target fabrics were sub-sampled. Careful attention was paid to avoid mixing of laminae and other fabrics when possible while still achieving the necessary mass for isotopic analyses. All isotope ratios are reported using delta notation in parts per thousand (\%). The carbonate carbon $\left(\delta^{13} \mathrm{C}_{\mathrm{c}}\right)$ and oxygen $\left(\delta^{18} \mathrm{O}_{\mathrm{c}}\right)$ isotope values of carbonate samples were analyzed for $\delta^{13} \mathrm{C}_{\mathrm{c}}$ and $\delta^{18} \mathrm{O}_{\mathrm{c}}$ at the University of Colorado Boulder Stable Isotope Laboratory (CUBES-SIL) on a Thermo Delta $\mathrm{V}$ continuous flow isotope ratio mass spectrometer (CF-IRMS) (Thermo Fisher Scientific, Waltham, MA, USA). Carbonate samples and standards were digested in phosphoric acid in a Thermo Gasbench II (Thermo Fisher Scientific) heated to $70^{\circ} \mathrm{C}$ to release $\mathrm{CO}_{2}$ to be analyzed by CF-IRMS. Carbonate isotope values were corrected for sample size dependence and then normalized to the Vienna Pee Dee Belemnite (VPDB) scale with a three-point calibration (Coplen et al., 2006) using NBS-18, Yule marble (CU YULE) and Harding Icelandic Spar (HIS; Table 3). The analytical precision based on replicate analyses of standard materials was $0.1 \%$ for both carbon and oxygen.

The oxygen isotopic composition of palaeo-lake water $\left(\delta^{18} \mathrm{O}_{\mathrm{w}}\right)$ was calculated using $\delta^{18} \mathrm{O}_{\mathrm{c}}$ values of all carbonate samples and converted to the Vienna Standard Mean Ocean Water (VSMOW) scale. The temperature of mineral formation must be assumed to calculate the oxygen isotopic composition of palaeo-lake water from $\delta^{18} \mathrm{O}_{c}$ due to the temperature dependence of the carbonatewater oxygen isotope fractionation factor ( $\square_{\text {carb-water }}$ McCrea, 1950; Clayton, 1959; Kim \& O’Neil, 1997). Carbonate clumped isotope-based thermometric measurements of a subset of the samples representing the different facies described in the Vermillion Creek section were made to reduce the uncertainty introduced by assuming lake water temperature in the Eocene.

This article is protected by copyright. All rights reserved 


\section{Carbonate clumped isotope analyses}

The advantage of clumped isotope thermometry $\left[\mathrm{T}\left(\Delta_{47}\right)\right]$ over the classic oxygen isotope thermometer is that $\mathrm{T}\left(\Delta_{47}\right)$ is independent of the bulk isotopic composition of the carbonate mineral. Instead, the clumped isotope thermometer is based on enhanced 'clumping' of rare, heavy isotopes of carbon and oxygen $\left({ }^{13} \mathrm{C}-{ }^{18} \mathrm{O}\right)$ at low temperatures (Eiler, 2007). The degree of clumping is quantified by the mass-47 anomaly $\left(\Delta_{47}\right)$, which is defined as the enrichment of the ${ }^{13} \mathrm{C}^{16} \mathrm{O}^{18} \mathrm{O}$ isotopologue of $\mathrm{CO}_{2}$ relative to a random distribution of the heavy isotopes among all $\mathrm{CO}_{2}$ molecules: $\Delta_{47}=\frac{{ }^{47} R}{{ }^{47} R *} \times 1000$ where ${ }^{47} \mathrm{R}=\left[{ }^{13} \mathrm{C}^{16} \mathrm{O}^{18} \mathrm{O}+{ }^{12} \mathrm{C}^{17} \mathrm{O}^{18} \mathrm{O}+{ }^{13} \mathrm{C}^{17} \mathrm{O}_{2}\right] /\left[{ }^{12} \mathrm{C}^{16} \mathrm{O}_{2}\right]$ and * denotes a stochastic distribution of isotopes. Thus, mineral formation temperatures can be used to calculate $\delta^{18} \mathrm{O}$ of ancient waters when paired with $\delta^{18} \mathrm{O}_{c}$ values of the same sample, which is measured concurrently with mass-47 measurements.

Clumped isotope measurements were made on 13 samples, with additional sub-samples of unique fabrics analyzed from three samples, at Caltech (Pasadena, CA, USA) and CUBES-SIL (see Appendix S1). Carbonate samples and standards were dissolved by phosphoric acid digestion in a common acid bath at $90^{\circ} \mathrm{C}$ to yield $\mathrm{CO}_{2}$ that could be measured by dual inlet IRMS. Evolved $\mathrm{CO}_{2}$ was passed through an 'autoline', which is an automated system of poropak and cryogenic traps for purifying the gases prior to analysis. Measurements of the purified $\mathrm{CO}_{2}$ were made on a ThermoScientific MAT253 gas source mass spectrometer at Caltech or a ThermoScientific MAT253Plus (Thermo Fisher Scientific) at CUBES-SIL. $\Delta_{47}$ and $\Delta_{48}$ were calculated relative to the working gas reference frame, and then projected into the Carbon Dioxide Equilibrium Scale (CDES; Dennis et al., 2011) using either standard $\mathrm{CO}_{2}$ gases heated to $1000^{\circ} \mathrm{C}(\mathrm{HG})$ and $\mathrm{CO}_{2}$ equilibrated with water at $25^{\circ} \mathrm{C}(\mathrm{EG})$ or carbonate standards to allow for interlaboratory comparison. $\Delta_{47}$ values were carbonate standard-corrected after converting to CDES.

Measurements of mass-48 are commonly used to screen sample gases for isobaric contaminants such as hydrocarbons, halocarbons and/or sulphur compounds. It is assumed that contaminants with interferences on mass-48 may also add excess signal to any of masses 44-47.

This article is protected by copyright. All rights reserved 
Samples in this study were screened for potential contamination by identifying ' $\Delta_{48}$ excess' as values that exceeded the $95 \%$ confidence interval of the line resulting from a York regression of the $\delta^{48}-\Delta_{48}$ HG data (the ' $\Delta_{48}$ line'). The first York regression used the internal errors of the measured values, and the second simulated external errors of the HG data, following the approach in Huntington et al. (2009) and further described in Appendix S1. The final external uncertainty $\left(\sigma_{\text {external }}\right)$ for each analysis was calculated by propagating the uncertainty of the HG line with the internal analytical error of each replicate using the matrix expression for error propagation in Huntington et al. (2009). One to five replicate powders of each sample were analyzed depending on sample mass limitations of individual fabrics. The $\Delta_{47, \mathrm{CDES}}$ errors of the sample averages from all replicates run across the four analytical periods were calculated by taking $\sigma_{\text {external }}$ of each sample analysis in quadrature. This standard error is multiplied by 1.96 to obtain the $95 \%$ prediction interval value.

Palaeotemperatures were calculated using T- $\Delta_{47}$ calibrations from Bonifacie et al. (2017) and Petersen et al. (2019); use of these calibrations is acceptable since the data use the IUPAC parameters for ${ }^{17} \mathrm{O}$ corrections (Brand et al., 2010). The reported errors were calculated by propagating the $95 \%$ prediction interval of the $\Delta_{47}$ sample averages through the T- $\Delta_{47}$ equation.

\section{RESULTS}

\section{Sedimentary facies characterization}

The primary facies of the Laney Member at Vermillion Creek were ooid grainstone, stromatolite boundstone, organic-rich shale and siltstone, and carbonaceous sandstone (Fig. 2). The ooid grainstones and microbialites were variably silicified. Grainstones were composed of ooids, ostracods and peloids, with minor quartz and feldspar (Table 1). Most stromatolitic horizons extended laterally for hundreds of metres along strike and were composed of columnar, micro-digitate, and crinklylaminated stromatolites with $<1$ to $3 \mathrm{~cm}$ of vertical relief ('low-relief'). Giant stromatolite horizons were also laterally continuous along strike (Fig. 1B) with 2 to $5 \mathrm{~m}$ of vertical relief. The giant stromatolite horizons, each built of two vertically stacked multi-metre mounds (Fig. 1C to E), occurred twice in the Vermillion Creek stratigraphy. Stromatolite rip-up clasts were observed in situ between the stacked mounds in the lower giant horizon. Hollow tube structures with decimetre-scale 
diameters were found at the base of some giants. Some, but not all, of these tubes contained lithified wood and bark impressions. Tube structures were not identified in the upper head of the lower giant stromatolite bioherm. It is possible that internal, subvertical tube structures exist within giants absent horizontal tubes.

Transmitted light microscopy revealed that both low-relief and giant stromatolites contained a variety of microfabrics, including crystal fans, crinkly laminations, micro-digitate columns, 'trapped and bound' sand grains, and micritic 'shrubs' (Fig. 2). Shrubby textures, trapped and bound grains, and aragonite fans were identified in a subset of samples collected from the immediate layers above the tube structures (GRFSWB3-1 and VC-18-15; Fig. 3).

Point counts of grainstones, packstones and wackestones revealed that a subset of ooid grainstones and quartz-rich wackestones contained K-feldspar and volcanic quartz with euhedral shapes and rare embayments (Table 1); within some ooid grainstones, these siliciclastic grains were the primary ooid nuclei. Point count data also revealed variations in the abundance of ostracods in grainstones, packstones and wackestones, with ostracods notably absent from the two ooid grainstone samples in the fine transect closely underlying the upper giant stromatolite horizon (Table 1). Several of the ooid grainstones with siliciclastic ooid nuclei (VC-18-10, VC-18-14 and VC-18-22; Fig. 2) were also characterized by poikilotopic cements and poikilotopic overgrowth or wholesale replacement of ooid cortices (see Fig. 4). Similar fabrics have been reported from other lacustrine carbonates (Valero Garces, 1993; Chowdhury \& Noble, 1996; Jeffrey, 2012), including elsewhere in the Green River Formation (Swierenga, 2007; Sarg et al., 2013).

Cathodoluminescence (CL) analysis revealed luminescence that ranged from bright to nonluminescent, with the dominant luminescence being a dull orange (Fig. 4). Concentric laminations of ooids, poikilotopic overgrowths and cements, as well as the micritic portions of stromatolite laminations, all typically exhibited relatively homogenous, dull orange luminescence (Fig. 4). Coarser-grained laminations within these same stromatolites were typically non-luminescent, while micritic laminations that bound isolated silicified laminations exhibited bright orange luminescence that was slightly brighter than most other micritic laminations. The CL analysis also clearly revealed the presence of dolomite microspar and spar cements, which were characterized by bright to non- 
luminescent banding of individual dolomite crystals. Finally, the distribution of luminescence within aragonite fans was patchy and alternated between dominantly bright orange luminescence and nonluminescent. Interestingly, the subtly distinct luminescence domains within the fan mounds ran perpendicular to the elongation direction of the crystal fan fabric, but parallel to the broader shape of the mound created by the fan (Fig. 4A).

Median ooid diameters $\left(D_{50}\right)$ ranged from 174 to $958 \mu \mathrm{m}$. Aragonite $\Omega$ estimates based on these measured ooid diameters ranged from $1.2 \pm 0.1$ to $5.7^{+1.7 /-2.4}$, with the highest values just below the second giant horizon (Figs 5 and 6). Based on the occurrence of aragonite fans within stromatolites in the Vermillion Creek section, ooid cortices were interpreted as originally aragonitic in composition. However, $\Omega$ estimates assuming a primary calcitic composition for ooids showed similar variation in magnitude (Fig. 5).

\section{Stable carbon, oxygen and clumped isotope compositions}

Carbon and oxygen stable isotope values were positively correlated, following the prediction of restricted basin hydrology (Fig. 7; Leng \& Marshall, 2004). The positive $\delta^{13} \mathrm{C}_{\mathrm{c}}$ and negative $\delta^{18} \mathrm{O}_{\mathrm{c}}$ values of the Vermillion Creek section fall within the spectrum between fresh and saline water (Leng \& Marshall, 2004), which is in agreement with sedimentological observations from this study and previous research. Additionally, the isotopic values recorded by each carbonate facies aligned with expectations for changing lake level - i.e. deep-water mudstone facies yielded the lowest $\delta^{13} C_{c}$ and $\delta^{18} \mathrm{O}_{\mathrm{c}}$ values: -0.1 to $3.0 \%$ and -11.7 to $-5.2 \%$ VPDB (Fig. 7), respectively. Ooid grainstone facies from the fine transect excepted, the grainstones yielded the highest $\delta^{13} \mathrm{C}_{\mathrm{c}}$ and $\delta^{18} \mathrm{O}_{\mathrm{c}}$ ranges: +2.0 to $6.9 \%$ and -4.8 to $-1.9 \%$ VPDB (Fig. 7), respectively. The fine transect (Fig. 6B) below the second stromatolite horizon yielded lower $\delta^{13} \mathrm{C}_{\mathrm{c}}$ and $\delta^{18} \mathrm{O}_{\mathrm{c}}$ values: +1.5 to $4.0 \%$ and -9.2 to $-6.6 \%$ VPDB, respectively. Grainstones with poikilotopic cements (VC-18-10 and VC-18-14), which were interpreted to have been strongly influenced by early diagenetic cementation and recrystallization through interactions with meteoric water, yielded some of the highest $\delta^{13} \mathrm{C}_{\mathrm{c}}$ values $(+6.9$ and $+5.8 \%$; Fig. 6A). Because of their diagenetic history, samples with poikilotopic cements were not used in interpretations and are marked with asterisks in Fig. 6. Finally, stromatolite $\delta^{13} \mathrm{C}_{\mathrm{c}}$ and $\delta^{18} \mathrm{O}_{\mathrm{c}}$ values

This article is protected by copyright. All rights reserved 
were in close agreement with the values presented in Awramik \& Buchheim (2015), ranging from 0.0 to $+5.4 \%$ and -11.0 to $-5.5 \%$ VPDB, respectively, with a narrower $\delta^{18} \mathrm{O}_{\mathrm{c}}$ range of -9.2 to $-6.1 \%$ o within the low-relief stromatolites.

Carbonate clumped isotope values $\left(\Delta_{47, \mathrm{CDES}, 25}\right)$ ranged from $0.665 \pm 0.009$ to $0.752 \pm 0.012 \%$ o (Fig. 8), corresponding to palaeotemperatures of $33.6 \pm 3.4^{\circ} \mathrm{C}$ to $5.4 \pm 3.3^{\circ} \mathrm{C}$ (Figs 6 and 8). An increase in $T\left(\Delta_{47}\right)$ occurred from the base to terminus of both giant stromatolite horizons and up section in the fine transect below the second giant horizon (Fig. 6). Calculated $\delta^{18} \mathrm{O}_{\mathrm{w}}$ of palaeo-lake water ranged from -11.1 to $-1.8 \pm 0.1 \%$ VSMOW. Subsamples across stromatolite laminae did not yield significant differences in $\delta^{18} \mathrm{O}_{\mathrm{c}}$ and $\Delta_{47}$ values (for example, VC-18-15 and VC-18-FT-04; Table $3)$.

\section{DISCUSSION}

\section{Sedimentary facies interpretation}

Field and hand sample observations support that the Lower LaClede Bed at Vermillion Creek recorded a dynamic, under-fill to balanced-fill interval of lacustrine deposition. Vertical stacking patterns of deep water (laminated, organic-rich mudstone and carbonate mudstone) and nearshore and shoreline facies (for example, ooid grainstones, quartz-rich wackestones and packstones) were interpreted to reflect repeated higher and lower lake level intervals through the deposition of this section. The two horizons of giant stromatolites were more or less bound by deeper water facies, with beds composed of facies indicative of shoreline deposition (for example, ooid grainstones and lowrelief microbial carbonates) immediately below both giants.

Observations of fabrics and microfacies associations by transmitted light and CL petrography supported field interpretation of the low-relief mounds and giants as stromatolites rather than tufa. Of the stromatolitic fabrics, aragonite fans are typically considered abiotic, while crinkly laminations, micro-digitate columns, 'trapped and bound' sand grains and micritic 'shrubs' are typically interpreted to have a microbial affinity (Bosak et al., 2013, and references therein). In particular, 
trapped and bound grains on steep surfaces have been identified as a unique signature of a microbial mat (Frantz et al., 2015). The CL characteristics of the laminated mounds provided further support for a microbial origin. The variation of luminescence mirroring microfabrics visible in transmitted light was also observed in modern laminated carbonate crusts formed in association with biofilms (Eymard et al., 2020). This further suggested that the dominant microfabrics and CL patterns (and thus geochemistry) reflect primary and earliest diagenetic carbonate formation, rather than significant later stage diagenesis.

Targeted geochemical analyses (i.e. $\delta^{18} \mathrm{O}, \mathrm{Na}$ and $\mathrm{Mg} / \mathrm{Ca}$ ) of micritic and aragonite fan microfabrics were used to differentiate between deep water and photic zone carbonate production elsewhere in Lake Gosiute (Frantz et al., 2014). In the Vermillion Creek section, shrubby textures, trapped and bound grains, and aragonite fans were all identified in the very basal layers of the giants (i.e. the tops of the tube structures) that were interpreted to record the initiation of stromatolite growth. Although the aragonite fans were interpreted as abiotic in origin, their CL characteristics were ambiguous. The aragonite crystals that define the fans radiate out normal to the underlying surfaces, while the CL patterns are broadly oriented surface-parallel (Fig. 4A and D). The increased occurrence of non-luminescence in the upper part of a fan in GRFSWB1-A (Fig. 4A) could reflect organic matter originally present in a laminated microfabric that was later engulfed by neomorphic growth of underlying aragonite fan crystals (Love \& Chafetz, 1988).

The two vertical stacks of mounds within each horizon were interpreted to reflect two subsequent initiations of stromatolite formation (Fig. 6). The distinct bounding stratigraphy of the two giant stromatolite horizons precludes the possibility of tectonic repetition of one giant stromatolite occurrence. Rip-up clasts sandwiched between the stacked mounds indicated a high energy environment in the interim before initiation of the subsequent giant. Awramik \& Buchheim (2015) interpreted the hollow tube structures at the base of some giants, combined with the localized presence of lithified wood and bark impressions, as evidence of a flooded forest. However, facies consistent with a pedogenic or palustrine environment or fabrics consistent with subaerial desiccation that might support this interpretation were not observed in the strata immediately underlying the giant

This article is protected by copyright. All rights reserved 
stromatolite horizons. Covered strata directly beneath the stratigraphically lower giant horizon limited interpretations of the precursor depositional environment. However, ooid grainstones and low-relief stromatolites dominated the strata directly below the upper giant horizon indicating a subaqueous environment.

The presence of K-feldspar and volcanic quartz grains in a subset of the samples was interpreted to reflect a flux of volcaniclastic silt and sand from the Absaroka Volcanic Province of north-west Wyoming and south-west Montana, which was active during Laney Member deposition (Fig. 9; Carroll et al., 2008; Smith et al., 2008). Based on the absence of compaction in these samples, as evidenced by preserved point contacts between adjacent grains, poikilotopic cements and overgrowths associated with ooids were interpreted to have formed via early diagenetic (i.e. precompaction) phreatic cementation and recrystallization (Quast et al., 2006; Beckner \& Mozley, 2009).

\section{What controls the growth and cessation of giant stromatolites?}

\section{Initiation of giant stromatolite formation}

The roles of lake level and carbonate saturation state. Carbonates stratigraphically below and at the cores of both basal giants were studied to assess the physicochemical conditions and allocyclic processes that triggered the onset of giant stromatolite formation. Isotopic, sedimentological and micropalaeontological observations indicated coincident increases in ${ }^{18} \mathrm{O} /{ }^{16} \mathrm{O}$ ratios, $\Omega_{\text {arag }}$ and salinity, respectively. These results were therefore interpreted to reflect positive feedback between hydroclimatic controls and geochemical factors that led to increased saturation states - decreased precipitation/evaporation (P/E) balance, decreased lake level and increased concentrations of solutes that contribute to salinity and alkalinity. The described physicochemical feedback may have been spurred by the cyclic climate of early Eocene hyperthermals combined with enhanced basin restriction due to hydrological reorganization and increased volcaniclastic sediment supply driven by adjacent Laramide tectonics (Carroll \& Bohacs, 1999; Smith et al., 2008; Birgenheier et al., 2020).

This article is protected by copyright. All rights reserved 
Evaporation preferentially removes ${ }^{16} \mathrm{O}$ from liquid water such that lakes with $\mathrm{P} / \mathrm{E}<1$ experience ${ }^{18} \mathrm{O}$ enrichments, and thus higher $\delta^{18} \mathrm{O}_{\mathrm{w}}$ values. In the ooid grainstone fine transect (FT) below the second giant horizon, $\delta^{18} \mathrm{O}_{\mathrm{w}}$ values increased from a low of $-7.9 \pm 0.5 \%$ to $-3.9 \pm 0.1 \%$ o VSMOW (Fig. 5). Further, $\delta^{18} \mathrm{O}_{\mathrm{w}}$ values from subsamples across $c a 2 \mathrm{~cm}$ of low-relief stromatolite laminae (VC-18-FT-04) were -7.4\% and -5.3\% VSMOW, indicative of relatively rapid evaporation prior to formation of the second giant. Increased $\delta^{18} \mathrm{O}_{\mathrm{w}}$ values were interpreted to record a decrease in lake level and volume prior to the initiation of giant stromatolite formation.

Ooid size-based $\Omega_{\text {arag }}$ estimates increased from $<2$ to $>5$ in the fine transect below the second giant horizon. The increase in $\Omega_{\text {arag }}$ was interpreted to have recorded evaporative concentration of solutes. Higher $\Omega_{\text {arag }}$ values would have resulted in more rapid carbonate precipitation rates (e.g. Zhong \& Mucci, 1989) and significant carbonate mass accumulation. Thus, high $\Omega_{\text {arag }}$ likely contributed to the ultimate size of the giant stromatolites.

Observations in this study also indicated that decreased lake levels led to increased salinity prior to giant stromatolite formation. Ostracod presence-absence provided a proxy for relative salinity through the Vermillion Creek section. Elsewhere in the Laney Member, the salinity tolerances of extant ostracods have been studied to create an interpretive framework for the physicochemical conditions of fossil ostracod habitats. Five ostracod species were identified in the LaClede Bed of the Laney Member at Antelope Creek, Wyoming (Ingalls \& Park, 2010). These species included both plant and mud dwellers, as well as free-swimming species, most comfortable in freshwater to brackish conditions. Ostracods were identified within the ooid grainstone facies in the lowermost $30 \%$ of identified grains) and uppermost (15 to $27 \%$ ) metres of the Vermillion Creek section, but they comprised $<2 \%$ of the sedimentary components from all samples from the giant stromatolite horizons and the strata between the two giant horizons and were notably absent from two ooid grainstones in the fine transect. The absence of ostracods was interpreted to reflect increased salinity prior to and during giant stromatolite growth relative to intervals at the base and top of the section. The basin experienced intervals of more or less freshwater infill during reconfiguration of basin architecture and upstream drainage reorganization associated with basin-bounding Laramide uplifts (Carroll et al.,

This article is protected by copyright. All rights reserved 
2008). During periods of lower lake level, lake water would have been more saline, exceeding salinity tolerance of extant species, and likely more alkaline, resulting in higher $\Omega_{\text {arag }}$ values.

The role of substrate size. In addition to the chemical impeti for carbonate precipitation, initiation of stromatolite growth required a substrate for nucleation. A commonality among many of the giants was accretion away from tube structures with preserved fossil wood or bark impressions (Figs 1D, 1E and 9A). Awramik \& Buchheim (2015) surmised that these tube structures were the remnants of erect tree trunks on which carbonate laminae accreted after flooding of a nearby forest mixed calcium-charged groundwater with saline-alkaline lake water. The scenario evoked by Awramik \& Buchheim (2015) assumed a very low Ca:ALK lake chemistry where freshwater $\mathrm{Ca}$ introduced to Ca-depleted alkaline lake water yielded rapid precipitation of carbonate - a process similar to shoreline tufa formation in modern and recent hyperalkaline lakes of the western US (for example, Mono Lake, California, USA or Pyramid Lake, Nevada, USA; Ca:ALK $c a 10^{-4}$ ). However, in low Ca:ALK basins, carbonate mineralization is restricted to shorelines and spring conduits; the deep water facies are carbonate-poor due to the Ca-limited character of the water column (e.g. Reddy, 1995; Nielsen \& DePaolo, 2013). Contrary to their low Ca:ALK hypothesis, carbonate was abundant in nearly all facies and palaeowater depths of the Vermillion Creek section. Importantly, lake bottom mudstones were carbonaterich. Nearly all grain types, including volcaniclastic grains transported from the Absaroka volcanic province and ostracods, were carbonate-coated as proto-ooids or well-developed ooids with thick cortices (Fig. 2). Together, these observations indicated that there was excess $\mathrm{Ca}$ for carbonate production $\left(\Omega_{\mathrm{arag}}>1\right)$ throughout Laney Member deposition. Volcaniclastic sediment from the Absaroka province filled the northern depocentres of the Green River Basin during Laney Member deposition. During this time, the Sand Wash Basin only periodically drained into the Piceance Basin (Smith et al., 2008). It is hypothesized that the influx of cations from silicate weathering paired with periodic basin restriction sustained the calcium supply and prolonged carbonate mineral supersaturation.

Furthermore, sedimentological and geochemical observations demonstrated that freshwateralkaline water mixing as a result of neither forest flooding events (Awramik \& Buchheim, 2015) nor

This article is protected by copyright. All rights reserved 
spring inputs (Jagniecki et al., 2021) was requisite for the initiation or accretion of multi-metre mounds. First, the strata immediately below the giants lack geological evidence for a long-lived shoreline forest environment, such as root traces, mottling and organic-rich facies (e.g. Pawlik \& Samonil, 2018). Second, both the ooid-based estimates of $\Omega_{\text {arag }}$ ( $c a 2$ to 5 throughout deposition) and the prevalence of carbonate precipitates in both shallow and deep-water facies demonstrated that carbonate production in the Sand Wash Basin did not require a freshwater calcium source. Carbonate facies dominated the LLB strata in the Sand Wash Basin in deep water mudstone, nearshore stromatolite and shoreline ooid grainstone facies (Figs 2 and 6). Rather, large substrates of any composition deposited in shallow water could have been opportunistically colonized by photosynthetic micro-organisms, with tree logs as only one such example. For instance, the upper stromatolite head of both giant horizons - each built of two vertically stacked heads - lacked an identifiable accretionary tube structure. Although the tube structure could have been internal if the tree was vertical at the time of initial accretion, the original inference of giants accreting from vertically oriented living trees may have been based on the giants that have been eroded from section and are no longer in their original orientation. All observed tube structures of the in situ giants were horizontally lying, or perpendicular to the vertical growth axis of the giants (Fig. 1D and E). As such, this study found it likely that the lower heads served as the nucleation centre for the second generation of giants.

The role of microbes. The initial layers of carbonate that coated the tube structures were characterized by microbial fabrics (Fig. 3). The initial $\mathrm{ca} 10 \mathrm{~cm}$ atop the tube structure at the base of the first giant horizon (VC-18-05) was radially dendritic. Petrographic analysis of the top of the tube structure of the upper giant horizon (VC-18-15 and GRFSWB3-1) revealed an initial layer of trapped and bound grains and micritic, crinkly laminations. Trapped and bound grains suggested that filamentous cyanobacteria or algae actively participated in accretion of carbonate to the initial surface (Fig. 9A and B). Although the incorporation of biological elements in carbonate growth does not necessitate that the mats served as templates for accreting laminae (Grotzinger \& Rothman, 1996; Grotzinger \& Knoll, 1999), the crinkly laminations were suggestive of mat morphology. Trapped and bound grains on surfaces steeper than the angle of repose provided strong evidence of cyanobacteria 
interacting with sediments (Frantz et al., 2015), requiring the site of giant initiation to have been within the photic zone.

However, aragonite fans - abiotic chemical precipitates - were identified immediately atop these mat-like fabrics (Figs 2 and 3). It was unsurprising that aragonite fans precipitated contemporaneously with micritic fabrics due to $\Omega_{\text {arag }}>5$ at the onset of giant formation. Where alternation of aragonite fans and microbial fabrics have been described elsewhere in the Green River Formation (Frantz et al., 2014), abiogenic fans were interpreted to have formed in cooler, deeper waters beneath a thermocline and micritic microfabrics to have formed when the lake was shallow and warm. Paired elevated $\delta^{18} \mathrm{O}$ values and sodium ion concentrations of micritic microfabrics and ${ }^{18} \mathrm{O}$-depleted and $\mathrm{Na}$-depleted values in the abiogenic fans supported the lake level interpretations (Frantz et al., 2014). On a broader scale, this study interprets the spatial relationship of these fabrics as evidence that microbial mats colonized the substrates from which giants accreted, while abiotic precipitation contributed significantly to the magnitude of carbonate production and, thus, ultimate size of the giants. Both modes of accretion were undoubtedly critical to the metre-scale heights. Decimetre-scale to metre-scale sedimentary structures are unstable under oscillatory flow (e.g. O'Donoghue \& Clubb, 2001), and thus, in the nearshore, higher energy environment, microbial cementation and trapping and binding would have been essential for upward growth (Fig. 9B). In deep water and in the absence of scour, surface normal growth by both microbially mediated accretion and abiotic precipitation (Fig. 9C) can proceed infinitely, limited only by carbonate saturation (e.g. Bosak et al., 2013).

\section{Growth/accretion of giant stromatolites}

The role of carbonate saturation state below the photic zone. After the initiation of giant growth from nucleation on a mat surface, petrographic and isotopic evidence indicated that giants continued to accrete carbonate laminae regardless of lake depth. To assess lake level and water temperature variability through the accretion of the giants, $\delta^{18} \mathrm{O}_{c}, \delta^{13} \mathrm{C}_{\mathrm{c}}$ and $\Delta_{47}$ were measured through both giant horizons and sub-sampled transects across individual hand samples. For example, five textures were 
sub-sampled along a ca $3 \mathrm{~cm}$ transect parallel to direction of accretion in the upper horizon (VC-1815), including crinkly laminated fabrics, micrite and microdigitate shrubs. $\delta^{18} \mathrm{O}_{c}$ and $\delta^{13} \mathrm{C}_{\mathrm{c}}$ exhibited positive covariation; from the base to the topmost laminae, $\delta^{18} \mathrm{O}_{c}$ decreased and then increased from $8.6 \%$ to $-10.2 \%$ to $-6.6 \%$ VPDB, and $\delta^{13} \mathrm{C}_{\mathrm{c}}$ from $0.8 \%$ o to $0.2 \%$ o to $3.1 \%$ VPDB (Table 3 ; $\sigma<0.1 \%$ ) In addition, $\Delta_{47}$-derived temperatures decreased from $24.8^{+4.0} /-4.6^{\circ} \mathrm{C}$ to $16.5^{+2.6} /-2.5^{\circ} \mathrm{C}$ and increased to 21.2 $2^{+5.0} /{ }_{-5.4}^{\circ} \mathrm{C}$ over the same $3 \mathrm{~cm}$. Based on closed-basin $\mathrm{C}$ and $\mathrm{O}$ isotope systematics (Leng \& Marshall, 2004) and following Frantz et al. (2014), the trends were interpreted to reflect lake level rise and fall on relatively short timescales with preservation of both abiotic and microbial fabrics. On longer timescales, $\delta^{18} \mathrm{O}_{c}, \delta^{13} \mathrm{C}_{\mathrm{c}}, \mathrm{T}\left(\Delta_{47}\right)$ and calculated $\delta^{18} \mathrm{O}_{\mathrm{w}}$ values all increased from the base to the terminus of the giants (Fig. 6A). A significant warming occurred across the first giant stromatolite horizon from $23.6^{+3.3 /}{ }_{-4.1}^{\circ} \mathrm{C}$ to $33.5^{+4.2} /{ }_{-5.0}{ }^{\circ} \mathrm{C}$ (Fig. 6A). From the base of the fine transect to the top of the uppermost giant, $\mathrm{T}\left(\Delta_{47}\right)$ increased from $19.7^{+3.6} /-4.2^{\circ} \mathrm{C}$ to $31.6^{+3.5} /-3.4^{\circ} \mathrm{C}$ - a warming of at least $5^{\circ} \mathrm{C}$ (Fig. 6A). The increased temperature could have contributed to faster precipitation rates (Burton \& Walter, 1987) and a productive environment for microbial communities. The temperature increase could be attributed to both a shift in location relative to the thermocline during lake level drawdown and/or regional warming, but the overall shift to higher $\mathrm{C}$ and $\mathrm{O}$ isotope values and temperatures were interpreted to record a warmer and shallower depositional environment.

In the intervals below both giant horizons, low-relief stromatolites were commonly composed of aragonite fans (Fig. 2). In the fine transect, low-relief stromatolites built of aragonite fans were interbedded with the ooid grainstones, commonly a shoreline facies, from which $\Omega_{\text {arag }}$ estimates of 5 to 6 were derived (Fig. 6B). The coexistence of high saturation states, shoreline facies and aragonite fans were interpreted as evidence that abiotic stromatolite growth occurred independent of lake depth (i.e. not just below the photic zone) and could co-precipitate with microbial fabrics where $\Omega_{\text {arag }}$ was exceptionally high.

In summary, the initiation of the giants was likely driven by co-occurrence of large accretionary substrates positioned within the photic zone and low lake level, yielding particularly high saturation states. Variably sized materials - from sand grains to tree trunks - were opportunistically 
colonized by microbial communities within the photic zone independent of substrate composition. Due to consistently high saturation states, the giants accumulated carbonate both within and below the photic zone. Based on new data, the following sequence for initiation and accretion of giant stromatolite growth was developed; onshore downed trees were: (i) transported to the shallow photic zone by runoff or storm events; (ii) colonized by photosynthetic bacteria (Fig. 9A); and (iii) accumulated carbonate both through microbial mediation of carbonate chemistry within the photic zone (Fig. 9B) and abiotic precipitation (Fig. 9C) independent of water depth.

\section{Cessation}

The role of siliciclastic influx. The apices of the upper giants in both horizons were unconformably overlain by quartz-rich grainstones. Following Awramik \& Buchheim (2015), it is hypothesized that an influx of siliciclastics from the Absaroka volcanic province covered the giants and their associated microbial mats, thereby sequestering photosynthetic cyanobacteria and algae from sunlight, shutting off carbonate accumulation. However, petrographic examination revealed that the siliciclastic grains in these grainstones were carbonate coated, serving as the nuclei for ooids or proto-ooids (Table 3 ). The carbonate-coated quartz and feldspar grains indicated that the depositional environment was still supersaturated with respect to calcium carbonate at the time of or soon after deposition, and thus further accretion could have occurred if these coated siliciclastics were conformable with the giant. Furthermore, depositional rates of siliciclastic influx could not have been particularly rapid because development of coated grains takes time. Therefore, it was more likely that a depositional hiatus due to subaerial exposure followed the cessation of giant growth.

The role of subaerial exposure due to lake level fall. In addition, the contacts between stacked giants were unconformable. In the lower horizon, an erosional contact was identified where a partial crosssection of several laminae of the lower giant were in contact with the overlying giant. The erosional contact was interpreted as evidence for subaerial exposure and differential weathering of the lowermost giant prior to initial accretion of the second giant in the lower horizon. This evidence partnered with the observation of hiatal surfaces at the apices of the upper giants in both horizons 
supported the conclusion that the cessation of giant stromatolite growth was repeatedly driven by subaerial exposure, and thus, lake level fall.

Trends in isotopic compositions and associated facies provided further evidence for lake level fall. Through both giant stromatolite horizons, clumped isotope-derived temperature and oxygen isotopic compositions increased (Fig. 6A), which were interpreted to record a shifting location relative to a thermocline and evaporative enrichment of ${ }^{18} \mathrm{O}$ with progressive lake level fall. In addition, multi-centimetre thick deposits of ooid grainstone were found adjacent to and within palaeotopographic lows between the giant stromatolites. The presence of the ooid grainstone facies in association with the giants was interpreted as a shift in the dominant mode of carbonate accumulation from stromatolite growth to formation, transport and net deposition of abundant ooid sand in the newly shallow environment. The abrupt transition to the mudstone deep-water facies above both giant horizons likely represented a depositional hiatus followed by a major transgression. Further, a marked shift in ooid nuclei composition from primarily carbonate nuclei in the ooid grainstone facies associated with the stromatolite horizon to the primarily quartz nuclei in the quartz-rich grainstone atop the stromatolites provided further evidence that the tops of the giants recorded hiatal surfaces. Thus, these sequences were interpreted as a record of lake level fall leading to subaerial exposure of the giants (Fig. 9D), followed by relatively rapid lake level rise related to the transition to basin overfill.

In addition, the return of $\Omega_{\text {arag }}$ estimates to $<2$ at the top of both giants could have reflected the consumption of alkalinity necessary to produce the carbonate mass that comprised the giants. Above

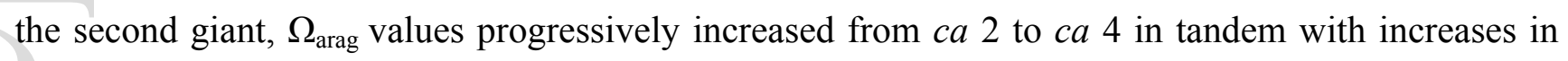
$\delta^{18} \mathrm{O}_{\mathrm{c}}$ from $c a-6 \%$ to $c a-2 \%$ VPDB. Lake Gosiute could have been returning to the ideal conditions for giant stromatolite formation, but no third stromatolite horizon was identified at the Vermilion Creek section.

In summary, the combined effects of increased saturation states during periods of decreased lake level and warm Eocene climate created uniquely favourable conditions for colonization of 
photosynthetic communities within the Sand Wash Basin of Lake Gosiute. Persistently high $\Omega_{\text {arag }}$ values facilitated high precipitation rates and, thus, in combination with the large substrates transported from land to the photic zone, determined the ultimate stature of the giants. When lake level dropped below the level of the giants or carbonate accumulation rates exceeded basin subsidence, subaerial exposure ceased further growth of the giants. During these intervals, the dominant mode of carbonate production shifted to ooid shoals which filled the palaeo-topographic relief between large mounds and in laterally extensive beds along strike, comprising the shoreline and nearshore depositional environment.

\section{Allocyclic controls on lake level variation?}

The Green River Formation shows a great deal of cyclicity; this cyclicity has been proposed to reflect a variety of temporal scales across numerous facies within the Formation (e.g. Awasereeleert et al., 2013; Walters et al., 2020). For example, elemental variability of the Skyline 16 core of the Parachute Creek member of the Green River Formation in the Uinta Basin showed cyclicity at a 3 to $5 \mathrm{~m}$ scale (Walters et al., 2020). In the Parachute Creek Member, cyclicity was attributed to orbital precession ( $c a 21$ to $23 \mathrm{kyr}$ duration). Assessing the scale and exact driver of cyclicity within the Vermillion Creek section is out of the scope of this study because it is a stretch to assume the twice occurrence of giant stromatolites represents a cycle. However, a broad scale comparison can be made between the Skyline core strata to similar thinly laminated beds of the organic-rich and carbonate-rich deeper facies of the Laney Member, allowing for the possibility that changes in lake level in the Sand Wash Basin could reflect orbital cycle-driven changes in hydroclimate.

For this time period, most of the orbitally-paced climate variability investigated has been the eccentricity-paced early Eocene hyperthermals (e.g. Lourens et al., 2005; Kirtland-Turner et al., 2014). Hydroclimate during hyperthermals has been investigated to better understand whether the predicted phenomenon of more extreme precipitation during rapid warming events is manifest in terrestrial records (Carmichael et al., 2018). In the western US, most evidence for more extreme precipitation comes from investigations of channel sand bodies related to the Palaeocene-Eocene Thermal Maximum (PETM), suggesting increased amount of rain and/or increased intensity of storms, even as palaeosol characteristics and palaeobotanical assemblages suggest drying (at least in

This article is protected by copyright. All rights reserved 
north-west Wyoming) during the PETM (Wing et al., 2005; Kraus and Riggins, 2008; Foreman et al., 2012; Foreman, 2013). Greater extremes in precipitation can produce such seemingly contradictory records, and to-date, it is not clear how changes to more extreme precipitation may manifest in lakes, particularly in effects on lake levels and carbonate chemistry. For the Green River Formation, lake level changes have been linked to eccentricity-paced carbon isotope excursions in the Wilkins Peak Member (Smith et al., 2014) to argue for a link between hyperthermals and lake levels. However, it has not yet been possible to definitively link any of these carbon isotope excursions to specific hyperthermals. Further work on the detailed chronostratigraphy of the Laney Member could determine whether the lake level changes described here coincide with Early Eocene hyperthermals and, if so, then these sections would be good candidates for better understanding the role of rapid global warming events on lake level changes.

\section{CONCLUSIONS}

This work presented a depositional model to serve as a framework for interpreting the hydrological, physicochemical and thermodynamic conditions under which giant stromatolites form. Two stratigraphic horizons of multi-metre stromatolites formed during a dynamic period of climate and tectonics in the Laney Member of the Green River Formation at Vermillion Creek. Sedimentological observations and geochemical and isotopic trends before, during and after giant formation were similar between the two intervals, demonstrating that their existence was not anomalous and the controls on presence-absence were not limited to isolated climatic events during the Early Eocene Climatic Optimum nor local expression of Laramide tectonics. The initiation of giant stromatolite growth required availability of large accretionary substrates within the photic zone coincident with high $\Omega_{\text {arag }}$ driven by lake level fall and a warm Eocene climate, yielding a consistently supersaturated environment. Petrographic observations of trapped and bound grains and crinkly laminations within the initial accretionary laminae atop the tube structures suggested that mat-forming micro-organisms were important to the initiation of giant growth. However, the giants continued to grow by abiotic mineralization when fluctuations in lake level positioned the giants in the dysphotic zone, as evidenced by alternating laminae of aragonite fans and fabrics of microbial affinity throughout the giants. Interbedded and interfingered abiotic and biogenic laminae within the initial few centimeters

This article is protected by copyright. All rights reserved 
of accretion demonstrated that, due to high $\Omega_{\text {arag }}$ values, abiotic aragonite precipitation occurred even in the presence of active mat communities. Ultimately, subaerial exposure halted giant stromatolite growth.

In summary, this study found that while the colonization of a large substrate by cyanobacteria was important to initiate stromatolite formation, the hydrological balance and warm Eocene temperatures - leading to high carbonate saturation state and rapid carbonate precipitation rates, respectively - were all more critical than microbial activity in determining the ultimate size of this unique stromatolite morphotype. The physicochemical parameter set that is favourable for giant stromatolite formation could explain the existence of exceptionally large stromatolites elsewhere in the Green River Formation and the carbonate rock record.

\section{DATA AVAILABILITY}

All samples were registered with International Geo Sample Numbers, which are listed in a table published on the Open Science Framework at https://osf.io/wb7uk/ (doi: 10.17605/OSF.IO/WB7UK). All raw and processed stable isotope data and data processing R Markdown files, as well as sedimentological data and additional petrographic images have been published in the OSF associated with this project, listed above. Github release of MATLAB code for ooid diameter-based omega calculations is archived on Zenodo (doi: 10.5281/zenodo.4279882).

\section{ACKNOWLEDGMENTS}

Field work and sampling was conducted on the current and ancestral homelands of the Eastern Shoshone and Ute nations. Laboratory work conducted at the University of Colorado Boulder was done on the unceded ancestral lands of the Ute, Cheyenne and Arapaho peoples. Laboratory analyses done at California Institute of Technology (Caltech) were conducted on the unceded lands of the Gabrielino-Tongva people. Samples were collected under a Bureau of Land Management Paleontological Resources Use Permit for Colorado COC 078834. E.J.T. thanks D. Postal and A. Sarmiento for mapping stromatolite mound distribution for a class project. The authors thank Nami Kitchen and Brett Davidheiser-Kroll for analytical support. Funding for this work was provided by 


\section{FIGURE AND TABLE CAPTIONS}

Fig. 1. (A) Regional and (B) local geology of the LaClede Bed of the Laney Member of the Green River Formation at Vermillion Creek. Regional geological map is adapted from Love (1970), Steidtmann et al. (1983) and Roehler (1993). Local geological map is adapted from Roehler (1993). (C) Low-relief stromatolites (**) were interbedded with ooid grainstones (\#) beneath the second giant stromatolite horizon. $(\mathbf{D})$ Giants $\left(^{\wedge}\right)$ grew vertically perpendicular to tube structures $(+)$ at their cores, interpreted as the accretionary points. Jacobs staff is $1.5 \mathrm{~m}$ in length. (E) Some low-relief stromatolites grew on the surfaces of giants, periodically forming whole laminae. Folding knife is approximately $8 \mathrm{~cm}$.

Fig. 2. Dominant facies of the LaClede Bed, Laney Member, Green River Formation. Petrographic images are in cross-polarized light with $1 \mathrm{~mm}$ scale bars. Stromatolites preserved both microbial and abiotic fabrics. Ooid grainstones and quartz-rich wackestones contained ostracods, microbial carbonate intraclasts (MCI) and quartz silt. Micrite within quartz-rich ooid grainstones to packstones was extensively replaced by poikilotopic cements; ooid cortices within these facies were commonly partially or completely replaced by poikilotopic calcite overgrowths.

Fig. 3. Initial carbonate growth atop the tube structures recorded biogenic and abiotic influences at the onset of giant stromatolite formation. The very first lamina in both GRFSWB3-1A (A) and (B) and VC-18-TT05-A (C) comprised crinkly laminated (CL) and micritic (M) textures as well as evidence for 'trapped and bound grains' (TB). Apparent biofabrics alternated with laminae of aragonite fans early in stromatolite growth (A) and (D). Scale bars are $5 \mathrm{~mm}$. (E) Coarse trapped and bound grains are found on overhanging stromatolite surfaces and between laminae.

Fig. 4. Cathodoluminescence of characteristic fabrics with paired transmitted cross-polarized light photomicrographs. Fabrics with bright luminescence have otherwise been characterized as primary [for example, homogeneous (C) or laminated (D) and (E) micrite, and aragonite fans (A) that comprise low-relief stromatolite mounds) or early diagenetic fabrics [for example, dolomite microspar

This article is protected by copyright. All rights reserved 
cements $(\mathbf{F})$ and $(\mathbf{H})$ and poikilotopic replacement of ooid cortices $(\mathbf{G})]$. (B) Ooids with quartz nuclei passively deposited between stromatolite mounds display dull to moderate luminescence. The locations of an image within its sample are given by the bracketed numbers after the sample name and referenced to thin section locations in Fig. S2.

Fig. 5. Point count component abundances for grainstones and packstones with $\Omega_{\text {arag }}$ estimates. Point count and ooid size data can be found in Tables 1 and 2. Grain types that comprise $<1 \%$ of a sample are not depicted.

Fig. 6. Carbon, oxygen and clumped isotope chemostratigraphy of: (A) the Vermillion Creek section of the Laney Member of the Green River Formation; and (B) a fine transect below the second giant stromatolite horizon.

Fig. 7. Facies-specific carbonate $\delta^{13} \mathrm{C}_{c}, \delta^{18} \mathrm{O}_{\mathrm{c}}$ and calculated $\delta^{18} \mathrm{O}_{\text {water }}$ values display positive C-O covariation. Grey triangles mark data from the upper giant horizon reported in Awramik \& Buchheim (2015).

Fig. 8. Facies-specific carbonate clumped and oxygen isotope data. Generally, warmer temperatures paired with ${ }^{18} \mathrm{O}$-enriched waters and vice versa, indicative of a thermocline. Stromatolite precipitation persisted in cool, deep waters $\left({ }^{18} \mathrm{O}\right.$-depleted) and warm, shallow waters by switching between abiotic and biotic modes of carbonate mediation.

Fig. 9. Depositional facies model for the Vermillion Creek section of the LaClede Bed. (A) At moderate lake levels, downed trees were transported from upland to shallow water nearshore environments atop ooid shoals. Downed trees were colonized by cyanobacteria mats. (B) Carbonate saturation states greater than one facilitated carbonate formation. Micritic carbonate laminae accreted and precipitated in association with the mats. Ooid lenses deposited between and within growing stromatolites. Low-relief stromatolites formed as laterally continuous layers atop and adjacent to the giants. (C) Water level rose, and carbonate saturation state lowered but maintained supersaturation 
such that carbonate formation continued below the photic zone as aragonite fans. (D) Lake level dropped significantly such that giants were subaerially exposed and ceased further accretion and growth. Eroded siliciclastic sediments form neighboring volcanic provinces deposited atop the giants. Due to supersaturation, these grains were coated with carbonate and sometimes replaced by poikilotopic cements. The modes of lake level and facies deposition described here are meant to represent distinct states of lake chemistry and carbonate formation. Some sequence of these states and transitional chemistry occurred at least twice at Vermillion Creek.

Table 1. Grain compositions determined via point counts.

Table 2. Ooid diameter-based aragonite saturation state estimates.

Table 3. Carbonate clumped, carbon and oxygen stable isotopes of the Laney Member of the Green River Formation at Vermillion Creek. Errors are reported as $1 \sigma$, reported to the tenth or thousandth of a permill (\%o) for analyses made on the Delta V or MAT253Plus (Thermo Fisher Scientific), respectively.

Appendix S1 (included as a separate file) Compilation of processed data for all samples, carbonate standards, and gas standards.

Fig. S1. Violin plot of carbon and oxygen stable isotopic composition by facies. Number of analyses by facies are given at the top of the plot.

Fig. S2. Locations of paired cross polarized and cathodoluminescence images in the main text and additional in the Open Science Framework are marked by red numbers. Higher resolution images of these thin sections are also in the Open Science Framework.

Fig. S3. Field photographs of characteristic macro-scale and meso-scale structures and morphologies.

(A) Macro-scale photograph of giant stromatolite double stacking pattern. The upper layer of 
stromatolites also demonstrates the nested nature of the discrete columns yet continuity of layers between neighboring columns. (B) Silicified and non-silicified carbonate ooid grainstones in close association with low-relief stromatolites and mat laminae. (C) Ex situ hand samples of digitate shrubs and pisoid grainstones. (D) The upper doubly stacked giant horizon demonstrating how the upper stromatolite used the lower stromatolite as its accretionary structure. (E) 'Cauliflower' texture on the outermost exposed layer of a stromatolite. (F) Stromatolite with pisolitic layer near its core and silicified low-relief stromatolites near knife. (G) Example of sub-sampled laminae of a stromatolite for analyses.

Fig. S4. Field photographs (A) to (E) and measured stratigraphic section (F) of the fine transect beneath the upper stromatolite horizon with detailed descriptions and sample locations.

Fig. S5. Tube structures and evidence for woody accretionary substrates. (A) Centimetres-scale hollow structure above upper surface of one giant stromatolite and near the base of a second giant stromatolite. (B) Macro-scale field photograph of a bioherm with several hollow tube structures at the cores of stromatolitic structures accretionary away from the tubes. (C) Bark impressions within a tube structure. (D) Silicified wood at the core of a stromatolite.

This article is protected by copyright. All rights reserved 


\section{REFERENCES}

Abels, H.A., Kraus, M.J. and Gingerich, P.D. (2013) Precession-scale cyclicity in the fluvial lower Eocene Willwood Formation of the Bighorn Basin, Wyoming (USA). Sedimentology, 60, 2467-2483.

Abels, H.A., Lauretano, V., van Yperen, A.E., Hopman, T., Zachos, J.C., Lourens, L.J., Gingerich, P.D. and Bowen, G.J. (2016) Environmental impact and magnitude of paleosol carbonate carbon isotope excursions marking five early Eocene hyperthermals in the Bighorn Basin, Wyoming. Clim. Past, 12, 1151-1163.

Arenas, C. and Jones, B. (2017) Temporal and environmental significance of microbial lamination: Insights from Recent fluvial stromatolites in the River Piedra, Spain. Sedimentology, 64, 1597-1629.

Arenas, C. and Pomar, L. (2010) Microbial deposits in upper Miocene carbonates, Mallorca, Spain. Palaeogeogr. Palaeoclimatol. Palaeoecol., 297, 465-485.

Arp, G., Bielert, F., Hoffmann, V.-E. and Löffler, T. (2005) Palaeoenvironmental significance of lacustrine stromatolites of the Arnstadt Formation ("Steinmergelkeuper", Upper Triassic, NGermany). Facies, 51, 419-441.

Awramik, S.M. and Buchheim, H.P. (2015a) Giant stromatolites of the Eocene Green River Formation (Colorado, USA). Geology, 43, 691-694.

Awramik, S.M. and Buchheim, P.H. (2015b) Giant stromatolites of the Eocene Green River Formation (Colorado, USA). Geology, 43, 691-694.

Bartley, J.K., Knoll, A.H., Grotzinger, J.P. and Sergeev, V.N. (2000) Lithification and fabric genesis in precipitated stromatolites and associated peritidal carbonates, Mesoproterozoic Billyakh Group, SIberia. Soc. Econ. Paleontol. Mineral. Spec. Publ. 67, 59-73.

Beckner, J.R. and Mozley, P.S. (2009) Origin and spatial distribution of early vadose and phreafic calcite cements in the Zia Formation, Albuquerque Basin, New Mexico, USA. Carbonate Cem. Sandstones Distrib. Patterns Geochem. Evol., 72, 27.

Birgenheier, L.P., Berg, M.D.V., Plink-Björklund, P., Gall, R.D., Rosencrans, E., Rosenberg, M.J., Toms, L.C. and Morris, J. (2020) Climate impact on fluvial-lake system evolution, Eocene Green River Formation, Uinta Basin, Utah, USA. GSA Bull., 132, 562-587.

Bonifacie, M., Calmels, D., Eiler, J.M., Horita, J., Chaduteau, C., Vasconcelos, C., Agrinier, P., Katz, A., Passey, B.H., Ferry, J.M. and Bourrand, J.J. (2017) Calibration of the dolomite clumped isotope thermometer from 25 to $350{ }^{\circ} \mathrm{C}$, and implications for a universal calibration

This article is protected by copyright. All rights reserved 
for all (Ca, Mg, Fe)CO3 carbonates. Geochim. Cosmochim. Acta, 200, 255-279.

Bosak, T., Knoll, A.H. and Petroff, A.P. (2013) The Meaning of Stromatolites. Annu. Rev. Earth Planet. Sci., 41, 21-44.

Bradley, M.D. (1995) Timing of the Laramide rise of the Uinta Mountains, Utah and Colorado.

Bradley, W.H. (1929) Algae reefs and oolites of the Green River Formation. Shorter Contrib. Gen. Geol., 203-223.

Brand, W.A., Assonov, S.S. and Coplen, T.B. (2010) Correction for the 170 interference in $\delta(13 C)$ measurements when analyzing $\mathrm{CO} 2$ with stable isotope mass spectrometry (IUPAC Technical Report). Pure Appl. Chem., 82, 1719-1733.

Burton, E.A. and Walter, L.M. (1987) Relative precipitation rates of aragonite and $\mathrm{M} \mathrm{g}$ calcite from seawater: Temperature or carbonate ion control? 4.

Cantine, M.D., Knoll, A.H. and Bergmann, K.D. (2020) Carbonates before skeletons: A database approach. Earth-Sci. Rev., 201, 103065.

Carmichael, M.J., Inglis, G.N., Badger, M.P.S., Naafs, B.D.A., Behrooz, L., Remmelzwaal, S., Monteiro, F.M., Rohrssen, M., Farnsworth, A., Buss, H.L., Dickson, A.J., Valdes, P.J., Lunt, D.J. and Pancost, R.D. (2017) Hydrological and associated biogeochemical consequences of rapid global warming during the Paleocene-Eocene Thermal Maximum. Glob. Planet. Change, 157, 114-138.

Carmichael, M.J., Lunt, D.J., Huber, M., Heinemann, M., Kiehl, J., LeGrande, A., Loptson, C.A., Roberts, C.D., Sagoo, N., Shields, C., Valdes, P.J., Winguth, A., Winguth, C. and Pancost, R.D. (2016) A model-model and data-model comparison for the early Eocene hydrological cycle. Clim. Past, 12, 455-481.

Carmichael, M.J., Pancost, R.D. and Lunt, D.J. (2018) Changes in the occurrence of extreme precipitation events at the Paleocene-Eocene thermal maximum. Earth Planet. Sci. Lett., 501, 24-36.

Carroll, A.R. and Bohacs, K.M. (1999) Stratigraphic classification of ancient lakes: Balancing tectonic and climatic controls. Geology, 27, 99-102.

Carroll, A.R., Doebbert, A.C., Booth, A.L., Chamberlain, C.P., Rhodes-Carson, M.K., Smith, M.E., Johnson, C.M. and Beard, B.L. (2008) Capture of high-altitude precipitation by a lowaltitude Eocene lake, Western US. Geology, 36, 791-794.

Chidsey, T.C., Vanden Berg, M.D. and Eby, D.E. (2015) Petrography and characterization of microbial carbonates and associated facies from modern Great Salt Lake and Uinta Basin's

This article is protected by copyright. All rights reserved 
Eocene Green River Formation in Utah, USA. Geol Soc Lond Spec Publ. doi: 10.1144/SP418.6

Chowdhury, A.H. and Noble, J.P.A. (1996) Origin, distribution and significance of carbonate cements in the Albert Formation reservoir sandstones, New Brunswick, Canada. Mar. Pet. Geol., 13, 837-846.

Clayton, R.N. (1959) Oxygen Isotope Fractionation in the System Calcium Carbonate-Water. J. Chem. Phys., 30, 1246-1250.

Coplen, T., Brand, W., Gehre, M., Groning, M., Meijer, H., Toman, B. and Verkouteren, R. (2006) New guidelines for d13C measurements. Anal. Chem., 78, 3439-2441.

Dennis, K., Affek, H., Passey, B., Schrag, D. and Eiler, J. (2011) Defining an absolute reference frame for 'clumped' isotope studies of CO2. Geochim. Cosmochim. Acta, 75, 7117-7131.

Doebbert, A.C., Carroll, A.R., Mulch, A., Chetel, L.M. and Chamberlain, C.P. (2010) Geomorphic controls on lacustrine isotopic compositions: Evidence from the Laney Member, Green River Formation, Wyoming. Geol. Soc. Am. Bull., 122, 236-252.

Eiler, J.M. (2007) "Clumped-isotope" geochemistry-The study of naturally-occurring, multiplysubstituted isotopologues. Earth Planet. Sci. Lett., 262, 309-327.

Frantz, C., Petryshyn, V.A. and Corsetti, F.A. (2015) Grain trapping and binding by filamentous cyanobacterial and algal mats: Implications for stromatolite microfabrics through time.

Frantz, C.M., Petryshyn, V.A., Marenco, P.J., Tripati, A., Berelson, W.M. and Corsetti, F.A. (2014) Dramatic local environmental change during the Early Eocene Climatic Optimum detected using high resolution chemical analyses of Green River Formation stromatolites. Palaeogeogr. Palaeoclimatol. Palaeoecol., 405, 1-15.

Fricke, H.C. and Wing, S.L. (2004) Oxygen isotope and paleobotanical estimates of temperature and 180-latitude gradients over North America during the early Eocene. Am. J. Sci., 304, $612-635$.

Graf, J.W., Carroll, A.R. and Smith, M.E. (2015) Lacustrine Sedimentology, Stratigraphy and Stable Isotope Geochemistry of the Tipton Member of the Green River Formation. In: Stratigraphy and Paleolimnology of the Green River Formation, Western USA (Ed. M.E. Smith and A.R. Carroll), Springer Netherlands, Dordrecht, 31-60.

Greenhalgh, J., Borsato, R., Mathew, F., Duncan-Jones, G., Pimenta, I., Marques da Silva, J. and Narciso da Silva, L. (2012) Petroleum plays and prospectivity in the Kwanza and Benguela Basins of offshore Angola.

This article is protected by copyright. All rights reserved 
Greenwood, D.R. and Wing, S.L. (1995) Eocene continental climates and latitudinal temperature gradients. Geology, 23, 1044-1048.

Grotzinger, J.P. (1990) Geochemical model for Proterozoic stromatolite decline. Am. J. Sci., 290-A, 80-103.

Grotzinger, J.P. and Knoll, a H. (1999) Stromatolites in Precambrian carbonates: evolutionary mileposts or environmental dipsticks? Annu. Rev. Earth Planet. Sci., 27, 313-358.

Grotzinger, J.P. and Rothman, D.H. (1996) An abiotic model for stromatolite morphogenesis. Nature, 383, 423-425.

Held, I.M. and Soden, B.J. (2006) Robust responses of the hydrological cycle to global warming. J. Clim., 19, 5686-5699.

Huntington, K.W., Eiler, J.M., Affek, H.P., Guo, W., Bonifacie, M., Yeung, L.Y., Thiagarajan, N., Passey, B., Tripati, a, Daëron, M. and Came, R. (2009) Methods and limitations of "clumped" CO2 isotope (Delta47) analysis by gas-source isotope ratio mass spectrometry. J. Mass Spectrom. JMS, 44, 1318-29.

Ingalls, B.R. and Park, L.E. (2010) Biotic and taphonomic response to lake-level fluctuations in the Greater Green River Basin (Eocene), Wyoming. PALAIOS, 25, 287-298.

Jagniecki, E.A., Lowenstein, T.K., Demicco, R.V., Baddouh, M., Carroll, A.R., Beard, B.L. and Johnson, C.M. (2021) Spring origin of Eocene carbonate mounds in the Green River Formation, Northern Bridger Basin, Wyoming, USA. Sedimentology, sed.12852.

Jeffrey, B.M. (2012) Rift basin-fill architecture of fluvial-lacustrine Lower Permian Lucaogou and Hongyanchi low-order cycles, Bogda mountains, NW China. MS, Wichita State University

Johnston, R.E. and Yin, A. (2001) Kinematics of the Uinta Fault System (southern Wyoming and northern Utah) during the Laramide Orogeny. Int. Geol. Rev., 43, 52-68.

Kim, S.-T. and O'Neil, J.R. (1997) Equilibrium and nonequilibrium oxygen isotope effects in synthetic carbonates. Geochim. Cosmochim. Acta, 61, 3461-3475.

Kirtland-Turner, S., Sexton, P.F., Charles, C.D. and Norris, R.D. (2014) Persistence of carbon release events through the peak of early Eocene global warmth. Nat. Geosci., 7, 748-751.

Lauretano, V., Littler, K., Polling, M., Zachos, J.C. and Lourens, L.J. (2015) Frequency, magnitude, and character of hyperthermal events at the onset of the Early Eocene Climatic Optimum. Clim. Past, 11, 1313-1324.

Leng, M.J. and Marshall, J.D. (2004) Palaeoclimate interpretation of stable isotope data from lake sediment archives. Quat. Sci. Rev., 23, 811-831.

This article is protected by copyright. All rights reserved 
Leopold, E.B. and MacGinitie, H.D. (1972) Development and affinities of Tertiary floras in the Rocky Mountains. In: Floristics and paleofloristics of Asia and eastern North America, Elsevier, 147-200.

Li, X., Trower, E.J., Lehrmann, D.J., Minzoni, M., Kelley, B.M., Schaal, E.K., Altiner, D., Yu, M. and Payne, J.L. (2020) Implications of giant ooids for the carbonate chemistry of Early Triassic seawater. Geology. doi: https://doi.org/10.1130/G47655.1

Lipinski, C.J., Franseen, E.K. and Goldstein, R.H. (2013) Reservoir analog model for oolitemicrobialite sequences, Miocene terminal carbonate complex, Spain. AAPG Bull., 97, 20352057.

Lourens, L.J., Sluijs, A., Kroon, D., Zachos, J.C., Thomas, E., Rohl, U., Bowles, J. and Raffi, I. (2005) Astronomical pacing of late Palaeocene to early Eocene global warming events. Nature, 435, 1083-1087.

Love, J.D. (1970) Cenozoic geology of the Granite Mountains area, central Wyoming. U.S. Geologial Survey, Washington, D. C.

M. Carminatti, Wolff, B., and Gamboa, L. (2008) New exploratory frontiers in Brazil. In: Proceedings of the 19th World Petroleum Congress, Madrid, Spain, 11.

Machlus, M.L., Ramezani, J., Bowring, S.A., Hemming, S.R., Tsukui, K. and Clyde, W.C. (2015) A strategy for cross-calibrating $\mathrm{U}-\mathrm{Pb}$ chronology and astrochronology of sedimentary sequences: An example from the Green River Formation, Wyoming, USA. Earth Planet. Sci. Lett., 413, 70-78.

Mancini, E.A., Llinás, J.C., Parcell, W.C., Aurell, M., Bádenas, B., Leinfelder, R.R. and Benson, D.J. (2004) Upper Jurassic thrombolite reservoir play, northeastern Gulf of Mexico. AAPG Bull., 88, 1573-1602.

Mancini, E.A., Parcell, W.C., Ahr, W.M., Ramirez, V.O., Llinás, J.C. and Cameron, M. (2008) Upper Jurassic updip stratigraphic trap and associated Smackover microbial and nearshore carbonate facies, eastern Gulf coastal plain. AAPG Bull., 92, 417-442.

Martin-Bello, L., Arenas, C., Andrews, J.E., Alonso-Zarza, A.M. and Marca, A. (2019) Lacustrine stromatolites as mutli-scale recorders of climate change: Insights from the Miocene Ebro Basin. Palaeogeogr. Palaeoclimatol. Palaeoecol., 530, 312-329.

Martin-Bello, L., Arenas, C. and Jones, B. (2019) Lacustrine stromatolites: Useful structures for environmental interpretation - an example from the Miocene Ebro Basin. Sedimentology, 66, 2098-2133.

This article is protected by copyright. All rights reserved 
McCrea, J.M. (1950) On the Isotopic Chemistry of Carbonates and a Paleotemperature Scale. J. Chem. Phys., 18, 849-857.

Milankovitch, M. (1941) Canon of insolation and the ice-age problem. Belgrade.

Monty, C.L.V. (1973) Precambrian background and Phanerozoic history of stromatolitic communities, an overview. Ann. Soc. Geol. Belg., 96, 585-624.

Nielsen, L.C. and DePaolo, D.J. (2013) Ca isotope fractionation in a high-alkalinity lake system: Mono Lake, California. Geochim. Cosmochim. Acta, 118, 276-294.

O’Donoghue, T. and Clubb, G.S. (2001) Sand ripples generated by regular oscillatory flow. Coast. Eng., 44, 101-115.

Pawlik, L. and Samonil, P. (2018) Biomechanical and biochemical effects recorded in the tree root zone - soil memory, historical contingency and soil evolution under trees. Plant Soil, 426, $109-134$.

Petersen, S.V., Defliese, W.F., Saenger, C., Daëron, M., Huntington, K.W., John, C.M., Kelson, J.R., Bernasconi, S.M., Colman, A.S., Kluge, T., Olack, G.A., Schauer, A.J., Bajnai, D., Bonifacie, M., Breitenbach, S.F.M., Fiebig, J., Fernandez, A.B., Henkes, G.A., Hodell, D., Katz, A., Kele, S., Lohmann, K.C., Passey, B.H., Peral, M.Y., Petrizzo, D.A., Rosenheim, B.E., Tripati, A., Venturelli, R., Young, E.D. and Winkelstern, I.Z. (2019) Effects of Improved 170 Correction on Interlaboratory Agreement in Clumped Isotope Calibrations, Estimates of Mineral-Specific Offsets, and Temperature Dependence of Acid Digestion Fractionation. Geochem. Geophys. Geosystems, $2018 \mathrm{GC} 008127$.

Pratt, B.R. (1982) Stromatolite decline-A reconsideration. 4.

Quast, A., Hoefs, J. and Paul, J. (2006) Pedogenic carbonates as a proxy for palaeo-CO2 in the Palaeozoic atmosphere. Palaeogeogr. Palaeoclimatol. Palaeoecol., 242, 110-125.

Reddy, M.M. (1995) Carbonate Precipitation in Pyramid Lake, Nevada. In: Mineral Scale Formation and Inhibition (Ed. Z. Amjad), Springer US, Boston, MA, 21-32.

Ritzma, H.R. (1955) Early Cenozoic history of the Sand Wash Basin, northwest Colorado. In: Guidebook to the Geology of Northwest Colorado, 36-40.

Roche, A., Vennin, E., Bouton, A., Olivier, N., Wattinne, A., Bundeleva, I., Deconinck, J.-F., Virgone, A., Gaucher, E.C. and Visscher, P.T. (2018) Oligo-Miocene lacustrine microbial and metazoan buildups from the Limagne Basin (French Massif Central). Palaeogeogr. Palaeoclimatol. Palaeoecol., 504, 34-59.

Roduit, N. (2020) JMicroVision: Image analysis toolbox for measuring and quantifying components

This article is protected by copyright. All rights reserved 
of high-definition images.

Roehler, H.W. (1993) Eocene climates, depositional environments, and geography, Greater Green River Basin, Wyoming, Utah, and Colorado. U.S. Department of the Interior, Washington, D. C.

Roehler, H.W. (1991) Revised stratigraphic nomenclature for the Wasatch and Green River Formations of Ecoene age, Wyoming, Utah, and Colorado.

Sarg, J.F., Huang, S., Tanavsuu-Milkeviciene, K. and Humphrey, J.D. (2013) Lithofacies, stable isotopic composition, and stratigraphic evolution of microbial and associated carbonates, Green River Formation (Eocene), Piceance Basin, Colorado. AAPG Bull., 97, 1937-1966.

Semikhatov, M.A., Gebelein, C.D., Cloud, P., Awramik, S.M. and Benmore, W.C. (1979) Stromatolite morphogenesis_progress and problems. Can. J. Earth Sci., 16, 992-1015.

Smith, M.E., Carroll, A.R. and Scott, J.J. (2015) Stratigraphic Expression of Climate, Tectonism, and Geomorphic Forcing in an Underfilled Lake Basin: Wilkins Peak Member of the Green River Formation. In: Stratigraphy and Paleolimnology of the Green River Formation, Western USA (Ed. M.E. Smith and A.R. Carroll), Springer Netherlands, Dordrecht, 61-102.

Smith, M.E., Carroll, A.R., Scott, J.J. and Singer, B.S. (2014) Early Eocene carbon isotope excursions and landscape destabilization at eccentricity minima: Green River Formation of Wyoming. Earth Planet. Sci. Lett., 403, 393-406.

Smith, M.E., Carroll, A.R. and Singer, B.S. (2008) Synoptic reconstruction of a major ancient lake system: Eocene Green River Formation, western United States. Geol. Soc. Am. Bull., 120, 54-84.

Smith, M.E., Chamberlain, K.R., Singer, B.S. and Carroll, A.R. (2010) Eocene clocks agree: coeval 40Ar/39Ar, U-Pb, and astronomical ages from the Green River Formation. Geology, 38, 527-530.

Smith, M.E., Singer, B. and Carroll, A. (2003) 40Ar/39Ar geochronology of the Eocene Green River Formation, Wyoming. Geol. Soc. Am. Bull., 115, 549-565.

Steidtmann, J., McGee, L. and Middleton, L. (1983) Laramide sedimentation, folding, and faulting in southern Wind River Range, Wyoming. AAPG Bull., 67, EP20262.

Sumner, D.Y. and Grotzinger, J.P. (2000) Late Archean aragonite precipitation: Petrography, facies associations, and environmental significance.

Surdam, R.C. and Stanley, K.O. (1979) Lacustrine sedimentation during the culminating phase of Eocene Lake Gosiute, Wyoming (Green River Formation). Geol. Soc. Am. Bull., 90, 93-110.

This article is protected by copyright. All rights reserved 
Swierenga, M. (2007) Depositional history and lateral variability of microbial carbonates, Three Mile Canyon and Evacuation Creek, eastern Uinta Basin, Utah. MS, Colorado School of Mines

Thrasher, B.L. and Sloan, L.C. (2010) Land cover influences on the regional climate of western North America during the early Eocene. Glob. Planet. Change, 72, 25-31.

Trower, E., Kivrak, L., Lamb, M.P. and Fischer, W.W. (2017) Experimental Evidence that Abrasion of Carbonate Sand is a Significant Source of Carbonate Mud. In: AGU Fall Meeting, New Orleans, LA, Oral Presentation.

Trower, E.J. (2020) The Enigma of Neoproterozoic Giant Ooids-Fingerprints of Extreme Climate? Geophys. Res. Lett., 47, 1-10.

Trower, E.J., Bridgers, S.L., Lamb, M.P. and Fischer, W.W. (2020) Ooid cortical stratigraphy reveals common histories of individual co-occurring sedimentary grains. J. Geophys. Res. Earth Surf., 125, e2019JF005452.

Trower, E.J., Cantine, M.D., Gomes, M.L., Grotzinger, J.P., Knoll, A.H., Lamb, M.P., Lingappa, U., O’Reilly, S.S., Present, T.M., Stein, N., Strauss, J.V. and Fischer, W.W. (2018) Active Ooid Growth Driven By Sediment Transport in a High-Energy Shoal, Little Ambergris Cay, Turks and Caicos Islands. J. Sediment. Res., 88, 1132-1151.

Valero Garces, B.L. (1993) Lacustrine deposition and related volcanism in a transtensional tectonic setting: Upper Stephanian-Lower Autunian in the Aragon-Bearn Basin, western Pyrenees (Spain-France). Sediment. Geol., 83, 133-160.

Westerhold, T., Marwan, N., Drury, A.J., Liebrand, D., Agnini, C., Anagnostou, E., Barnet, J.S.K., Bohaty, S.M. and Vleeschouwer, D.D. (2020) An astronomically dated record of Earth 's climate and its predictability over the last 66 million years. 1387, 1383-1387.

Wilf, P., WING, S.L., Greenwood, D.R. and Greenwood, C.L. (1998) Using fossil leaves as paleoprecipitation indicators: An Eocene example. Geology, 26, 203-206.

Wing, S.L. and Greenwood, D.R. (1993) FOSSILS AND FOSSIL CLIMATE - THE CASE FOR EQUABLE CONTINENTAL INTERIORS IN THE EOCENE. Philos. Trans. R. Soc. Lond. Ser. B-Biol. Sci., 341, 243-252.

Zhong, S. and Mucci, A. (1989) Calcite and Aragonite Precipitation from Seawater Solutions of Various Salinities: Precipitation Rates and Overgrowth Compositions. Chem. Geol., 78, 283299.

This article is protected by copyright. All rights reserved 
Table 1. Grain type abundances of grainstones and packstones: 300 grains were counted per thin section.

\begin{tabular}{|c|c|c|c|c|c|c|c|c|}
\hline Sample & Ooid & $\begin{array}{c}\text { Volcanic } \\
\text { quartz }\end{array}$ & $\begin{array}{c}\text { Other } \\
\text { quartz }\end{array}$ & $\begin{array}{c}\text { Feldspa } \\
\mathbf{r}\end{array}$ & $\begin{array}{c}\text { Ostraco } \\
\mathbf{d}\end{array}$ & $\begin{array}{c}\text { Proto- } \\
\text { ooid }\end{array}$ & Peloid & Facies \\
\hline \hline VC-18-03 & 44.00 & 1.33 & 4.33 & 0.00 & 30.00 & 0.33 & 20.00 & Ooid grainstone \\
VC-18-08 & 1.33 & 0.00 & 94.67 & 0.00 & 1.67 & 2.33 & 0.00 & Quartz-rich wackestone \\
VC-18-10 & 5.67 & 3.67 & 38.67 & 2.67 & 0.33 & 28.67 & 20.33 & Quartz-rich grainstone \\
VC-18-12 & 15.33 & 5.33 & 13.67 & 0.00 & 3.00 & 58.33 & 4.33 & Ooid grainstone \\
VC-18-14 & 22.33 & 2.33 & 9.33 & 0.33 & 1.33 & 61.34 & 3.00 & Ooid grainstone \\
VC-18-18 & 24.67 & 1.00 & 10.67 & 0.00 & 1.67 & 48.33 & 13.67 & Ooid grainstone \\
VC-18-20 & 47.33 & 0.00 & 0.00 & 0.00 & 27.00 & 0.00 & 25.67 & Ooid grainstone \\
VC-18-22 & 19.67 & 1.00 & 13.33 & 1.00 & 1.00 & 58.33 & 5.67 & Ooid grainstone \\
VC-18-24 & 60.00 & 0.00 & 0.00 & 0.00 & 14.67 & 1.33 & 24.00 & Ooid grainstone \\
VC-18-FT-14 95.00 & 0.00 & 0.00 & 0.00 & 0.00 & 0.00 & 5.00 & Ooid grainstone \\
VC-18-FT-16 & 97.00 & 0.00 & 0.00 & 0.00 & 0.00 & 0.00 & 3.00 & Ooid grainstone \\
\hline
\end{tabular}

${ }^{*}$ A proto-ooid is an ooid with only a single layer cortex. 
Table 2. Ooid diameter-based aragonite saturation state estimates.

\begin{tabular}{|c|c|c|c|c|c|}
\hline Sample & \begin{tabular}{|c|}
$\begin{array}{c}\text { Stratigraphic } \\
\text { height }(\mathrm{m})\end{array}$ \\
\end{tabular} & $\begin{array}{c}D_{50} \\
(\mathrm{~mm})\end{array}$ & $\sigma(\mathrm{mm})$ & $n$ & $\Omega$ aragonite \\
\hline VC-18-24 & 441.25 & 0.66 & 0.14 & 347 & 3.96 \\
\hline VC-18-20 & 41.20 & 0.58 & 0.15 & 298 & 3.50 \\
\hline VC-18-22 & 35.00 & 0.24 & 0.06 & 401 & 1.70 \\
\hline VC-18-18 & 29.00 & 0.17 & 0.05 & 400 & 1.17 \\
\hline GRFSWB2-2' & 26.00 & 0.43 & 0.13 & 287 & 2.70 \\
\hline VC-18-FT-16 & 23.90 & 0.88 & 0.19 & 354 & 5.24 \\
\hline VC-18-FT-14 & 23.74 & 0.96 & 0.22 & 226 & 5.70 \\
\hline VC-18-14 & 20.50 & 0.23 & 0.06 & 400 & 1.64 \\
\hline VC-18-12 & 15.50 & 0.25 & 0.06 & 400 & 1.75 \\
\hline VC-18-10 & 11.20 & 0.21 & 0.06 & 400 & 1.51 \\
\hline VC-18-03 & 0.95 & 0.33 & 0.09 & 191 & 2.15 \\
\hline
\end{tabular}


Table 3. Carbonate clumped, carbon and oxygen stable isotopes of the Laney Member of the Green River Formation at Vermillion Creek.

\begin{tabular}{|c|c|c|c|c|c|c|c|c|c|c|}
\hline Sample & Lithotype & $\begin{array}{c}\text { Stratigraphic } \\
\text { height }(m)\end{array}$ & $\begin{array}{c}\delta^{13} \mathrm{C}_{\mathrm{c}} \\
\left(\%{ }^{\circ} \mathrm{VPDB}\right) \\
\end{array}$ & $\begin{array}{c}\delta^{18} O_{c} \\
(\% o \text { PDB }) \\
\end{array}$ & $\Delta_{47,90^{\circ} \mathrm{C}}$ & $\begin{array}{c}\Delta_{47, \text { std-corr }} \\
\text { CDES, } 25^{\circ} \mathrm{C} \\
\end{array}$ & $\mathbf{T}\left(\Delta_{47, \mathrm{Bon}}\right)\left({ }^{\circ} \mathbf{C}\right)$ & $\mathrm{T}\left(\Delta_{47, \mathrm{Pet}}\right)\left({ }^{\circ} \mathbf{C}\right)$ & $\begin{array}{c}\delta^{18} O_{\text {water }} \\
(\% \text { VSSMOW) }\end{array}$ & \begin{tabular}{|c}
$\begin{array}{c}n \\
\text { clumped } \\
\text { replicates }\end{array}$ \\
\end{tabular} \\
\hline VC-18-01 & "Mudstone & 0.35 & $-0.1 \pm 0.1$ & $-5.3 \pm 0.2$ & & & & & & \\
\hline VC-18-02 & Mudstone & 0.50 & $1.786 \pm 0.005$ & $-5.185 \pm 0.009$ & 0.661 & $0.728 \pm 0.011$ & $7.9 \pm 3.0$ & $12.7+3.2 /-3.7$ & $-5.4 \pm 0.3$ & 4 \\
\hline VC-18-03 & Ooid grainstone & 0.95 & $3.6 \pm 0.1$ & $-3.8 \pm 0.1$ & & & & & & \\
\hline VC-18-04 & Quartz-rich grainston $\epsilon$ & 1.20 & $4.777 \pm 0.003$ & $-4.756 \pm 0.011$ & 0.661 & $0.749 \pm 0.013$ & $7.7+3.5 /-3.4$ & $6.1 \pm 3.8$ & $-6.4 \pm 0.6$ & 3 \\
\hline VC-18-05 & Giant stromatolite & 8.00 & $0.972 \pm 0.003$ & $-9.215 \pm 0.008$ & 0.606 & $0.694 \pm 0.011$ & $23.3+3.4 /-3.3$ & $23.6+3.3 /-4.1$ & $-7.1 \pm 0.1$ & 4 \\
\hline VC-18-06 & Giant stromatolite & 9.75 & & & & & & & & \\
\hline VC-18-07 & Giant stromatolite & 11.00 & $0.1 \pm 0.01$ & $-11.0 \pm 0.1$ & & & & & & \\
\hline VC-18-07a & Giant stromatolite & 11.00 & $1.775 \pm 0.002$ & $-9.541 \pm 0.008$ & 0.597 & $0.685 \pm 0.011$ & $26.2+3.4 /-3.3$ & $26.8+3.3 /-4.2$ & $-6.8 \pm 0.1$ & 6 \\
\hline VC-18-07c & Giant stromatolite & 11.00 & $0.699 \pm 0.002$ & $-10.673 \pm 0.00 \leqslant$ & 0.579 & $0.667 \pm 0.012$ & $32.3+4.2 /-4.1$ & $33.5+4.2 /-5.0$ & $-6.6 \pm 0.1$ & 6 \\
\hline VC-18-08 & Quartz-rich grainston $\epsilon$ & 4.75 & $2.0 \pm 0.1$ & $-3.9 \pm 0.1$ & & & & & & \\
\hline VC-18-09A & Low-relief stromatolite & 6.00 & & & & & & & & \\
\hline VC-18-09B & Low-relief stromatolite & 6.00 & $0.425 \pm 0.004$ & $-9.217 \pm 0.009$ & 0.664 & $0.752 \pm 0.012$ & $7.0 \pm 3.0$ & $5.4 \pm 3.3$ & $-11.1 \pm 0.6$ & 3 \\
\hline VC-18-10 & Quartz-rich grainston $\epsilon$ & 11.20 & $6.925 \pm 0.004$ & $-4.033 \pm 0.174$ & 0.657 & $0.745 \pm 0.011$ & $8.9+3.0 /-2.9$ & $7.5+3.2 /-3.3$ & $-5.4 \pm 0.4$ & 3 \\
\hline VC-18-11 & Mudstone & 14.30 & $1.161 \pm 0.001$ & $-11.666 \pm 0.00 \xi$ & 0.585 & $0.673 \pm 0.011$ & $30.1+3.6 /-3.5$ & $31.1+3.5 /-4.4$ & $-8.1 \pm 0.1$ & 6 \\
\hline VC-18-12 & Ooid grainstone & 15.50 & $5.264 \pm 0.003$ & $-2.633 \pm 0.011$ & 0.640 & $0.728 \pm 0.014$ & $13.5+4.0 /-3.9$ & $12.5+4.4 /-4.3$ & $-2.9 \pm 0.4$ & 3 \\
\hline VC-18-13 & Mudstone & 19.00 & $1.895 \pm 0.004$ & $-9.727 \pm 0.008$ & 0.627 & $0.715 \pm 0.009$ & $17.2 \pm 2.7$ & $17.1+2.4 /-3.5$ & $-9.0 \pm 0.1$ & 7 \\
\hline VC-18-14 & Ooid grainstone & 20.50 & $5.8 \pm 0.1$ & $-4.4 \pm 0.2$ & & & & & & \\
\hline VC-18-15A & Giant stromatolite & 25.75 & $0.769 \pm 0.005$ & $-8.594 \pm 0.009$ & 0.603 & $0.691 \pm 0.012$ & $24.4+4.0 /-3.8$ & $24.8+4.0 /-4.6$ & $-6.3 \pm 0.2$ & 2 \\
\hline VC-18-15B & Giant stromatolite & 25.75 & $0.180 \pm 0.002$ & $-10.174 \pm 0.006$ & 0.626 & $0.714 \pm 0.008$ & $17.3+2.4 /-2.3$ & $16.5+2.6 /-2.5$ & $-9.6 \pm 0.2$ & 1 \\
\hline VC-18-15C & Giant stromatolite & 25.75 & $0.015 \pm 0.004$ & $-9.639 \pm 0.008$ & 0.622 & $0.710 \pm 0.010$ & $18.7+2.9 /-2.8$ & $18.4+2.8 /-3.4$ & $-8.6 \pm 0.2$ & 4 \\
\hline VC-18-15D & Giant stromatolite & 25.75 & $2.790 \pm 0.005$ & $-7.136 \pm 0.014$ & 0.613 & $0.701 \pm 0.016$ & $21.3+4.8 /-4.6$ & $21.2+5.0 /-5.4$ & & 2 \\
\hline VC-18-15W & Giant stromatolite & 25.75 & $3.1 \pm 0.1$ & $-6.6 \pm 0.1$ & & & & & & \\
\hline VC-18-16 & Giant stromatolite & 25.50 & $0.9 \pm 0.1$ & $-8.0 \pm 0.1$ & & & & & & \\
\hline VC-18-17 & Giant stromatolite & 26.00 & $2.7 \pm 0.1$ & $-8.1 \pm 0.1$ & & & & & & \\
\hline VC-18-18 & Giant stromatolite & 29.00 & $5.360 \pm 0.004$ & $-5.476 \pm 0.008$ & 0.583 & $0.671 \pm 0.009$ & $30.9+3.2 /-3.1$ & $31.6+3.5 /-3.4$ & $-1.8 \pm 0.1$ & 3 \\
\hline VC-18-19 & Ooid grainstone & 36.50 & $6.8 \pm 0.1$ & $-1.9 \pm 0.1$ & & & & & & \\
\hline VC-18-20 & Ooid grainstone & 41.20 & $6.2 \pm 0.1$ & $-1.9 \pm 0.1$ & 0.606 & $0.671 \pm 0.008$ & $23.3+2.5 /-2.5$ & $23.2+2.7 /-2.8$ & $0.1 \pm 0.1$ & \\
\hline VC-18-21 & Mudstone & 34.00 & & & & & & & & \\
\hline VC-18-22 & Ooid grainstone & 35.00 & & & & & & & & \\
\hline VC-18-22A & Ooid grainstone & 35.00 & $5.2 \pm 0.1$ & $-4.8 \pm 0.1$ & & & & & & \\
\hline VC-18-23 & Mudstone & 39.00 & $1.049 \pm 0.004$ & $-8.187 \pm 0.008$ & 0.609 & $0.697 \pm 0.010$ & $22.5+3.3 /-3.2$ & $24.0+3.3 /-3.2$ & $-6.0 \pm 0.1$ & 8 \\
\hline VC-18-24 & Ooid grainstone & 41.25 & & & & & & & & \\
\hline VC-18-24B & Ooid grainstone & 41.25 & $6.2 \pm 0.1$ & $-2.4 \pm 0.2$ & & & & & & \\
\hline VC-18-24W & Ooid grainstone & 41.25 & $6.0 \pm 0.1$ & $-1.9 \pm 0.1$ & & & & & & \\
\hline VC-18-FS-01 & Giant stromatolite & 25.75 & $1.4 \pm 0.1$ & $-7.6 \pm 0.1$ & & & & & & \\
\hline VC-18-FS-02 & 2 Giant stromatolite & 25.65 & & & & & & & & \\
\hline VC-18-FS-03 & 3 Giant stromatolite & 24.50 & $4.6 \pm 0.1$ & $-6.9 \pm 0.1$ & & & & & & \\
\hline VC-18-FS-04 & 4 Giant stromatolite & 24.55 & & & & & & & & \\
\hline VC-18-FS-05 & 5 Giant stromatolite & 25.45 & & & & & & & & \\
\hline VC-18-FT-01 & Mudstone & 22.70 & & & & & & & & \\
\hline VC-18-FT-02 & Low-relief stromatolite & 22.80 & $2.766 \pm 0.003$ & $-6.337 \pm 0.005$ & 0.606 & $0.694 \pm 0.009$ & $23.4+2.7 /-2.6$ & $23.2+3.0 /-2.9$ & $-4.3 \pm 0.1$ & 4 \\
\hline VC-18-FT-03 & Mudstone & 23.00 & $3.0 \pm 0.1$ & $-5.8 \pm 0.1$ & & & & & & \\
\hline VC-18-FT-04A & ALow-relief stromatolite & 23.08 & $0.844 \pm 0.618$ & $-8.683 \pm 0.009$ & 0.618 & $0.706 \pm 0.012$ & $19.9+3.7 /-3.5$ & $19.7+3.7 /-4.2$ & $-7.4 \pm 0.5$ & 4 \\
\hline VC-18-FT-04B & BLow-relief stromatolite & 23.09 & $4.074 \pm 0.613$ & $-6.931 \pm 0.008$ & 0.613 & $0.701 \pm 0.010$ & $21.2+3.1 /-3.0$ & $21.2+3.1 /-3.6$ & $-5.3 \pm 0.2$ & 6 \\
\hline VC-18-FT-05 & Ooid grainstone & 23.11 & $2.8 \pm 0.1$ & $-7.3 \pm 0.1$ & & & & & & \\
\hline VC-18-FT-06 & Ooid grainstone & 23.17 & & & & & & & & \\
\hline VC-18-FT-07 & Ooid grainstone & 23.19 & $1.5 \pm 0.1$ & $-8.9 \pm 0.1$ & & & & & & \\
\hline VC-18-FT-08 & Ooid grainstone & 23.41 & & & & & & & & \\
\hline VC-18-FT-09 & Ooid grainstone & 23.49 & & & & & & & & \\
\hline VC-18-FT-10 & Low-relief stromatolite & 23.55 & $3.783 \pm 0.003$ & $-7.835 \pm 0.009$ & 0.578 & $0.666 \pm 0.009$ & $32.5 \pm 3.1$ & $33.4+3.4 /-3.5$ & $-3.8 \pm 0.0$ & 4 \\
\hline VC-18-FT-11 & Low-relief stromatolite & 23.68 & & & & & & & & \\
\hline VC-18-FT-12 & Ooid grainstone & 23.69 & $2.0 \pm 0.1$ & $-9.2 \pm 0.1$ & & & & & & \\
\hline VC-18-FT-13 & Ooid grainstone & 23.77 & $3.873 \pm 0.003$ & $-7.161 \pm 0.006$ & 0.595 & $0.683 \pm 0.007$ & $26.9+2.2 /-2.1$ & $28.0+1.5 /-3.2$ & $-4.2 \pm 0.1$ & 4 \\
\hline VC-18-FT-14 & Ooid grainstone & 23.74 & & & & & & & & \\
\hline VC-18-FT-15 & Ooid grainstone & 23.97 & $4.0 \pm 0.1$ & $-6.6 \pm 0.1$ & & & & & & \\
\hline VC-18-FT-16 & Ooid grainstone & 23.90 & & & & & & & & \\
\hline A-01-5cm & Ooid grainstone & & $1.8 \pm 0.1$ & $-7.6 \pm 0.0$ & & & & & & \\
\hline $\mathrm{A}-02-35 \mathrm{~cm}$ & Ooid grainstone & & $2.4 \pm 0.0$ & $-6.6 \pm 0.0$ & & & & & & \\
\hline $\mathrm{A}-03-70 \mathrm{~cm}$ & Ooid grainstone & & $2.0 \pm 0.0$ & $-7.0 \pm 0.0$ & & & & & & \\
\hline B- $01-5 \mathrm{~cm}$ & Ooid grainstone & & $0.8 \pm 0.0$ & $-8.6 \pm 0.4$ & & & & & & \\
\hline B- $02-55 \mathrm{~cm}$ & Ooid grainstone & & $2.3 \pm 0.0$ & $-7.5 \pm 0.1$ & & & & & & \\
\hline B-03-100cm & Giant stromatolite & & $1.6 \pm 0.1$ & $-6.8 \pm 0.0$ & & & & & & \\
\hline C-01-0cm & Ooid grainstone & & $0.8 \pm 0.0$ & $-8.9 \pm 0.1$ & & & & & & \\
\hline C- $-02-35 \mathrm{~cm}$ & Giant stromatolite & & $2.9 \pm 0.1$ & $-7.1 \pm 0.0$ & & & & & & \\
\hline C-03-95cm & Giant stromatolite & & $4.1 \pm 0.1$ & $-5.7 \pm 0.0$ & & & & & & \\
\hline D- $01-5 \mathrm{~cm}$ & Ooid grainstone & & $1.5 \pm 0.1$ & $-8.2 \pm 0.1$ & & & & & & \\
\hline D- $02-45 \mathrm{~cm}$ & Ooid grainstone & & $2.3 \pm 0.0$ & $-7.3 \pm 0.0$ & & & & & & \\
\hline D-03-80cm & Ooid grainstone & & $5.4 \pm 0.0$ & $-5.4 \pm 0.0$ & & & & & & \\
\hline
\end{tabular}




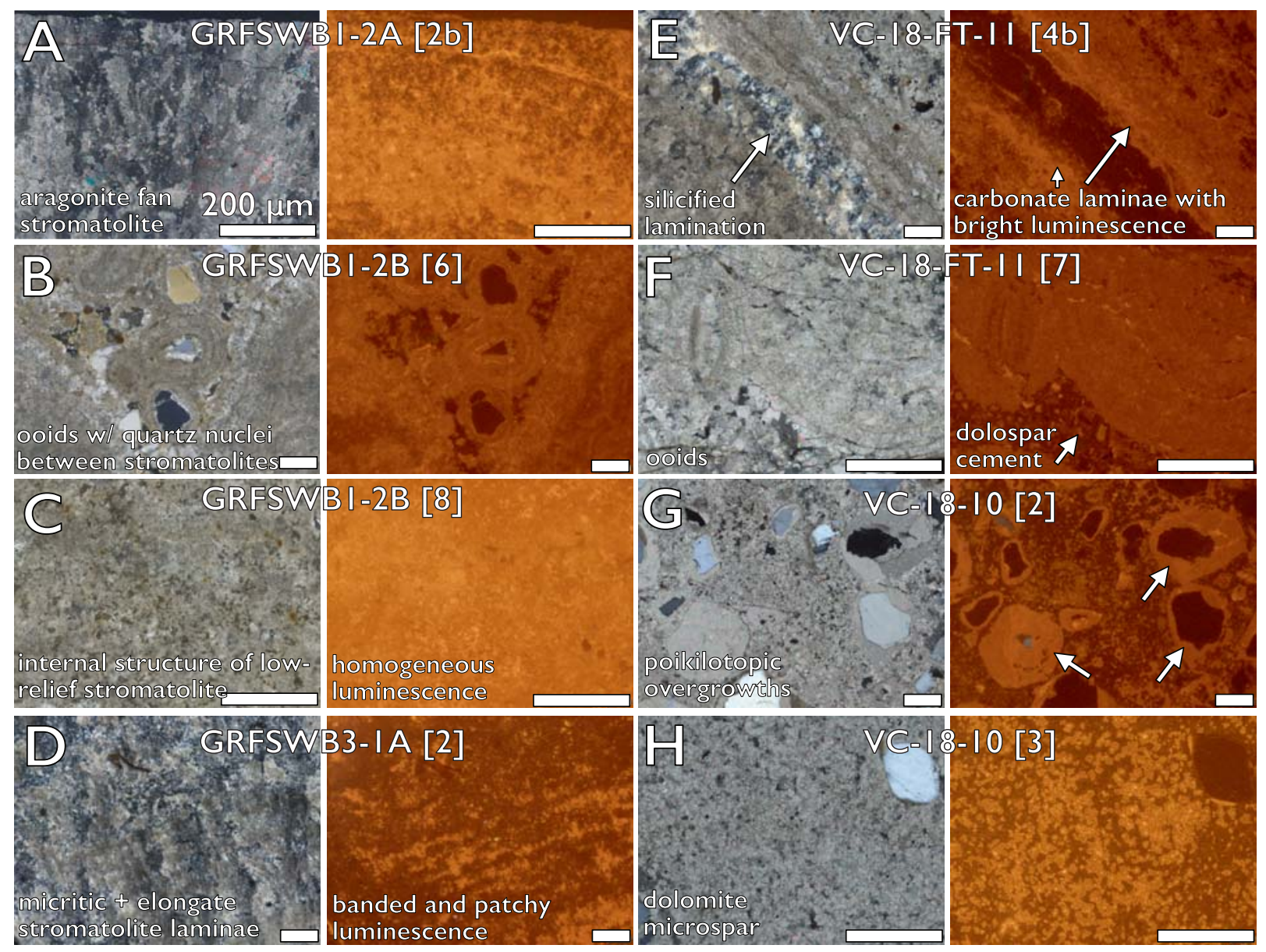




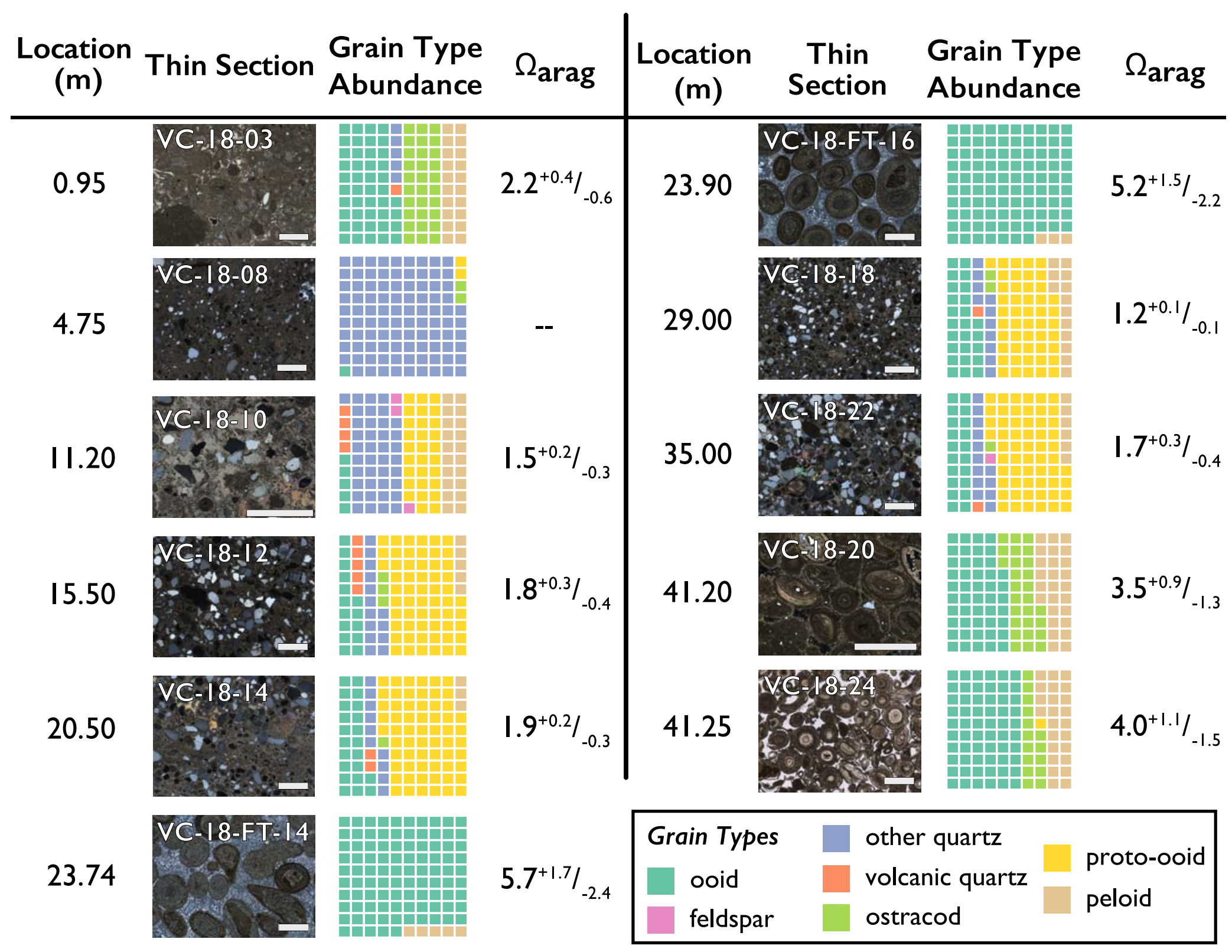


A Vermillion Creek section, Laney Member, Green River Formation

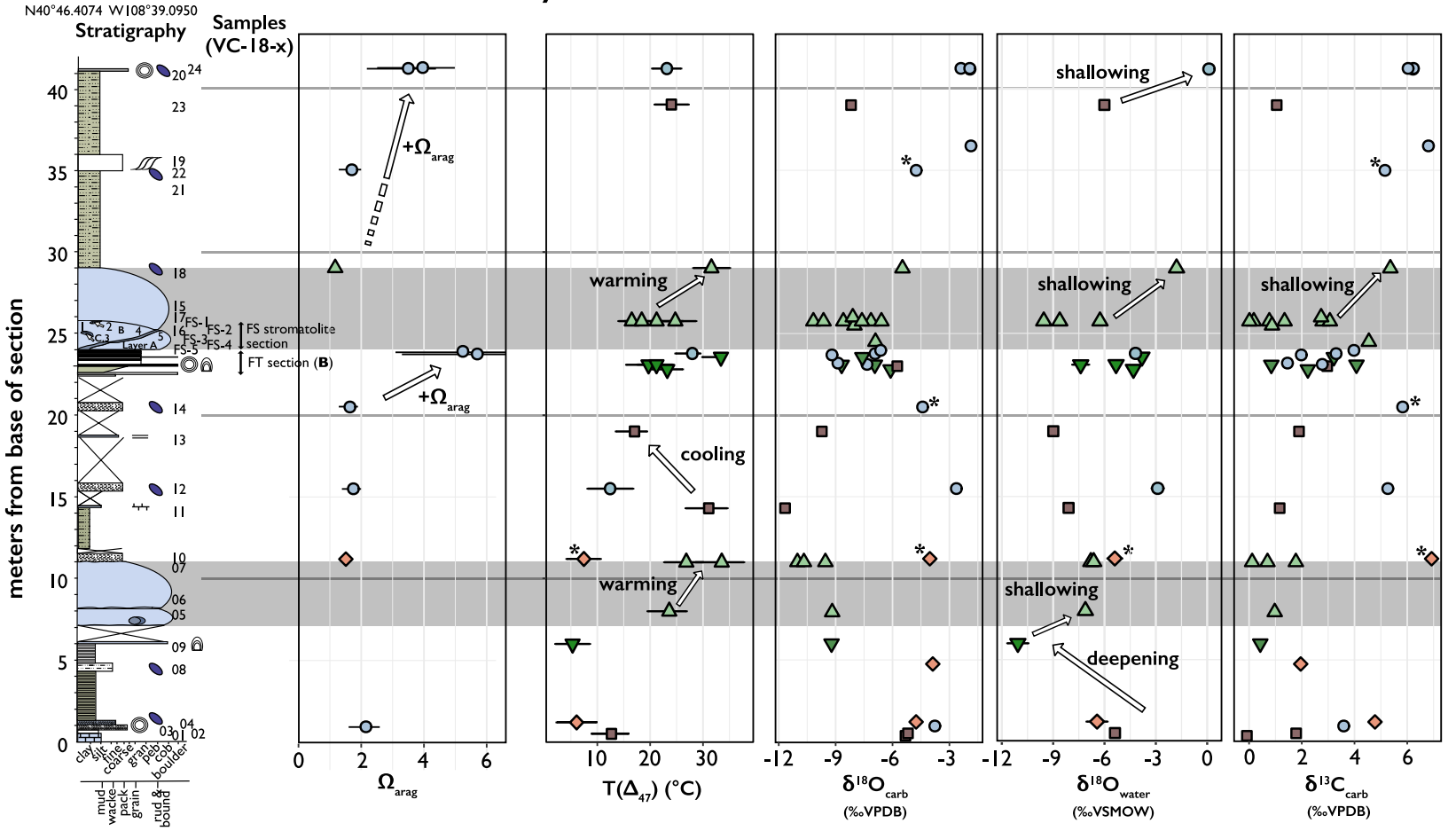

\section{B Fine transect at base of second "giant" horizon}
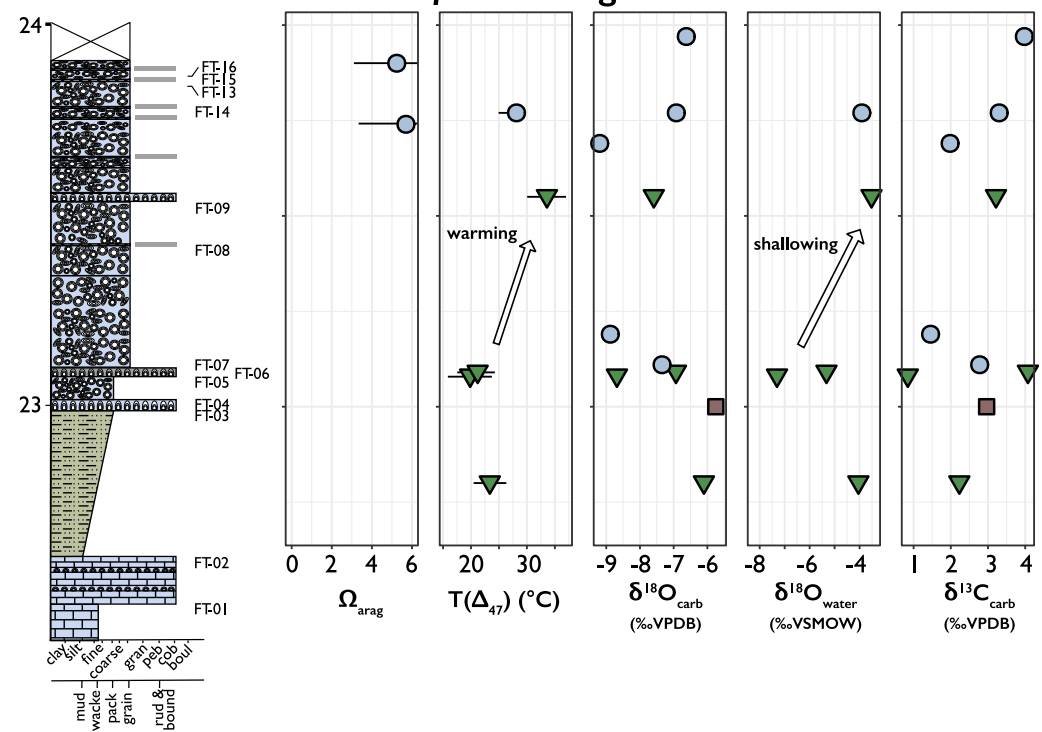

\section{Facies}

$\square$ mudstone

$\nabla$ low-relief stromatolite

$\bigcirc$ ooid grainstone

$\diamond$ quartz-rich grainstone

$\triangle$ giant stromatolite

* poikilotopic cements

silicified lenses

Dr low-angle cross bedding

( low-relief stromatolite

(2) tube structure

(Q) ooid

ostracods

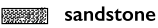

shale

[.:-1) laminated siltstone

limestone

(\%)VPDB)

(\%०VSMOW)

(\%०VPDB)

carbonate-rich

organic-rich

silicified 

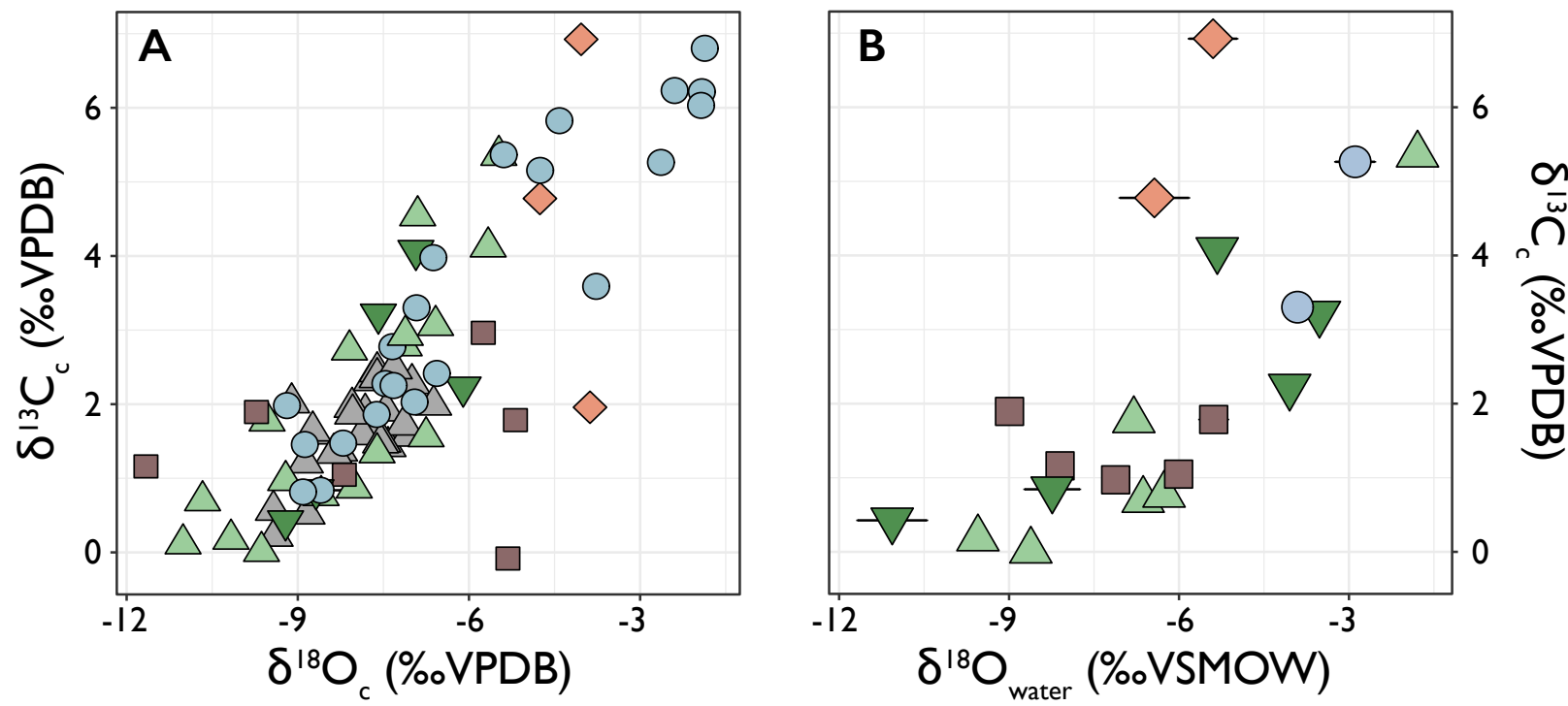

Facies $\triangle$ "giant" stromatolite $\diamond$ quartz-rich grainstone $\nabla$ low-relief stromatolite $\square$ mudstone $\bigcirc$ ooid grainstone $\triangle$ upper giant horizon, from Awramik \& Buchheim (2015) 


\section{$\mathrm{T}\left(\Delta_{47}\right)\left({ }^{\circ} \mathrm{C}\right)$}
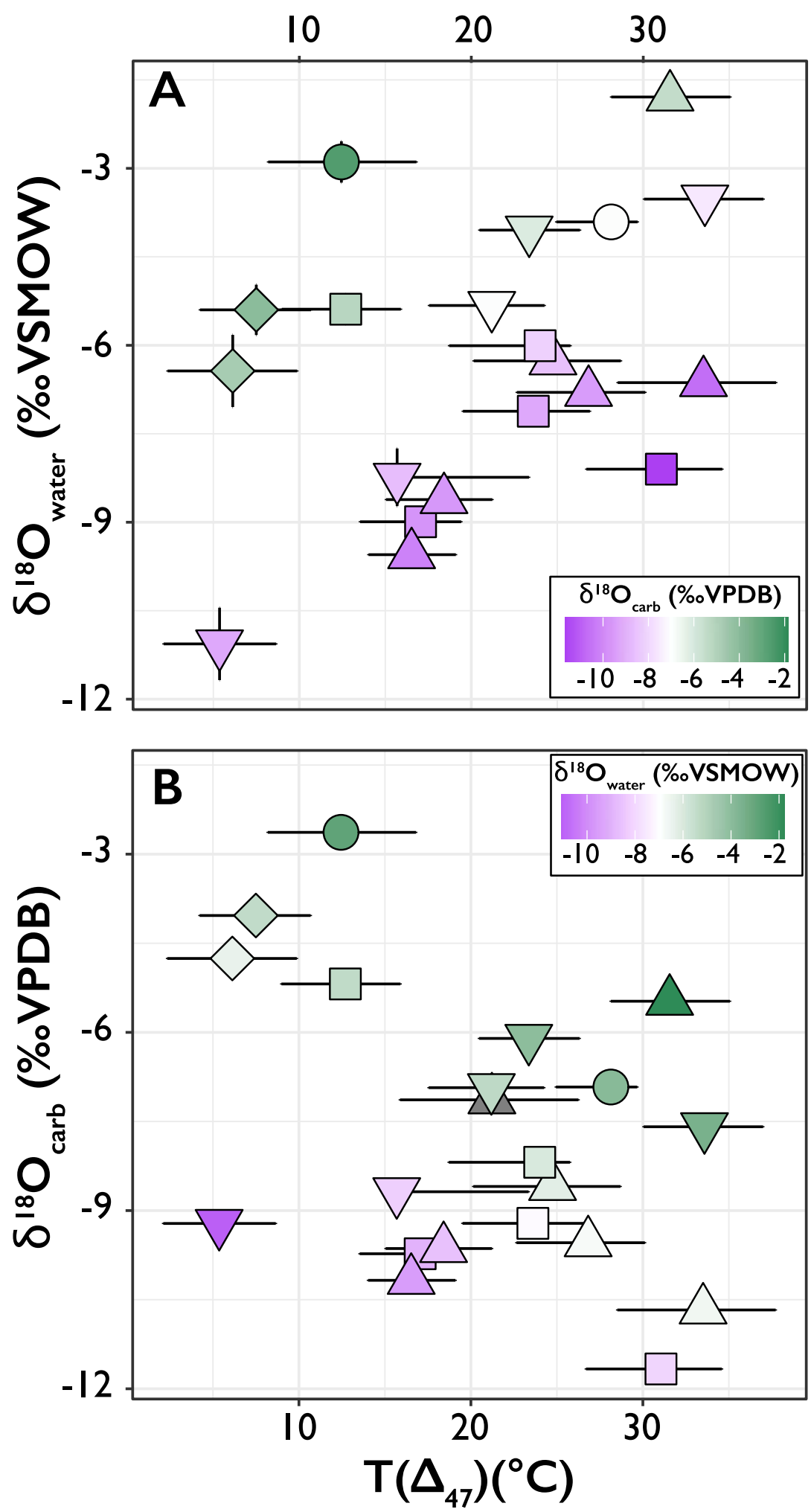

Facies $\triangle$ "giant" stromatolite $\diamond$ quartz-rich grainstone $\nabla$ low-relief stromatolite $\square$ mudstone $\bigcirc$ ooid grainstone 
